$$
\begin{aligned}
& \text { توظيف الهندية في توليد الافكار المعمارية في التوجه الاحيائي لعشرينات } \\
& \text { القزن العثرين }
\end{aligned}
$$

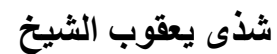

$$
\begin{aligned}
& \text { مدرس/قسم الهندسة المعمارية/جامعة الموصل } \\
& \text { الملخص المعلمرية }
\end{aligned}
$$

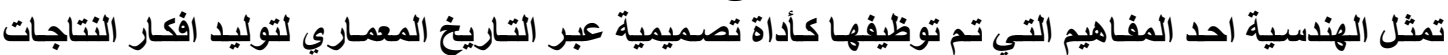

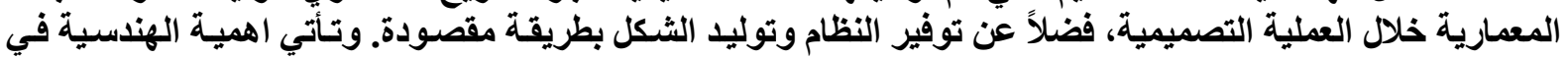

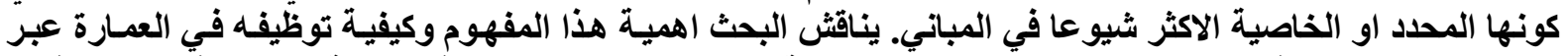

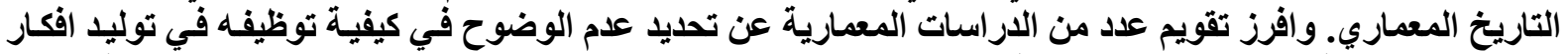

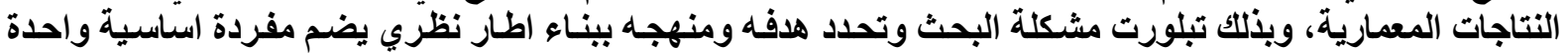

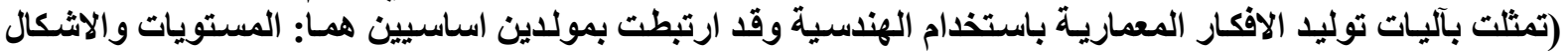

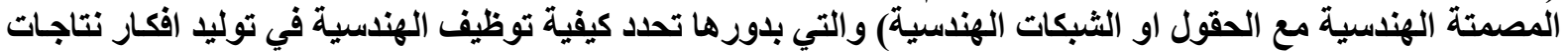

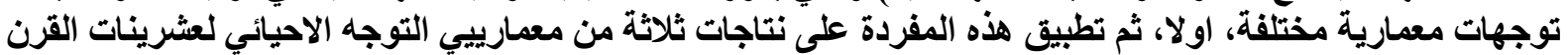

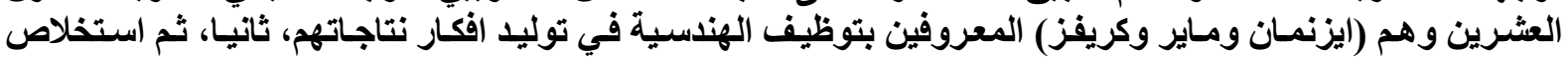

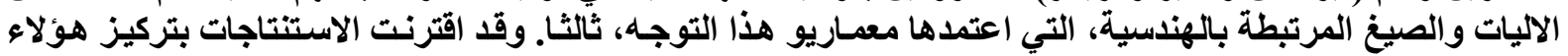

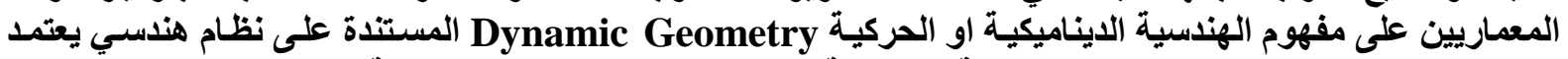

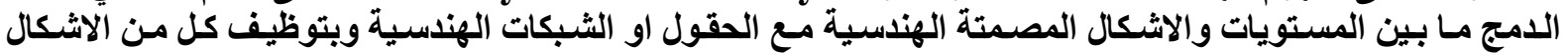

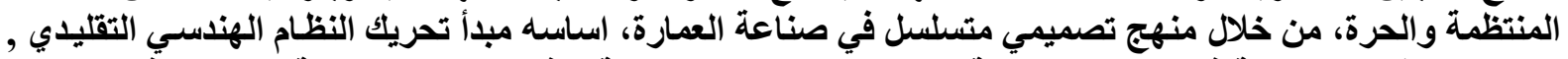

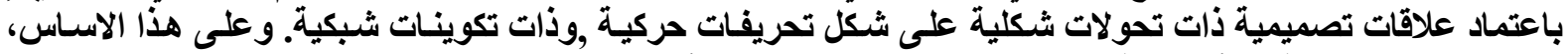

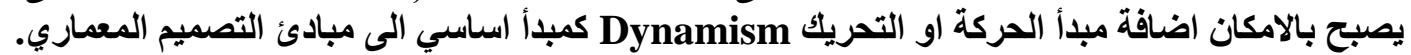

\title{
The Employment of Geometry in Creating Architectural Ideas in Twenties Revivalism Trend of the $20^{\text {th }}$ Century
}

\section{Shatha Yacoub Al-Sheikh}

\section{Abstract}

Geometry is presented as one of the concepts which has been employed as a design tool for creating architectural ideas in the design process throughout architectural history, as well as providing order and creating form intentionly. The importance of geometry has emerged, because it is considered the single most common determinant or characteristic in buildings. The paper discusses the importance of this concept and its employment as a formative idea during architectural history.

Thus the objectives of the paper and its problem have been formed by building theoretical framework consisting of one main item of detailed theoretical field as the following: (procedures of creating architectural ideas by employing geometry which is, in term connected by two primary generators; geometric planes and solids with geometric fields or grids), which specifies procedures of employing geometry in creating architectural ideas in different architectural trends, firstly, then the application of this item on the products of three architects: Meier, Eisenman and Graves from the twenties Revivalism trend of the $20^{\text {th }}$ century, secondly, Finally, concluding procedures and paradigms, which had been employed by architects of this trend in creating ideas, thirdly.

Conclusions have been declared, concentration on the concept known as dynamic geometry which is based on a geometric order depending on the combination of both planes and solids with geometric fields, and the employment of both regular and unique free forms, throughout design systemization in making architecture, based on the dynamism of traditional geometric order, depending on selected design relations of formal elisions in the form of dynamic modifications and of grid compositions. Thus, dynamism or movement can be added as a primary principle to the different architecture design principles.

Keywords: geometric transformation, New York five architects, formative ideas.

$$
\text { قبل: } 2010 \text { - } 11 \text { - } 11
$$$$
\text { أستلم: } 2009 \text { - } 4 \text { - } 2
$$ 


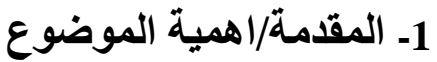

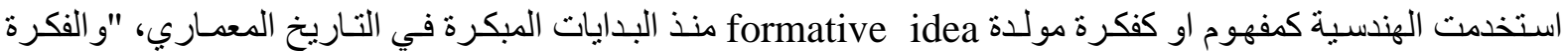

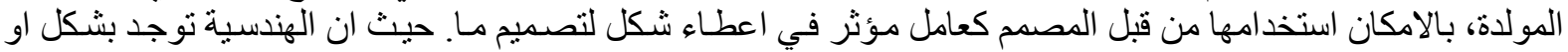

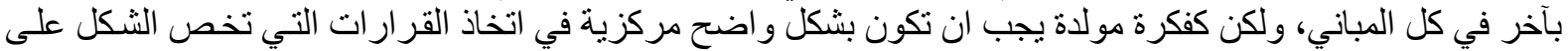

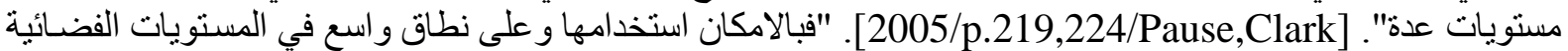

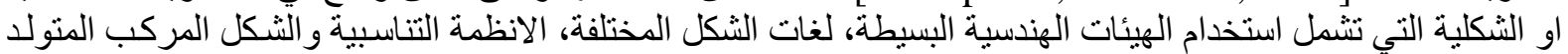

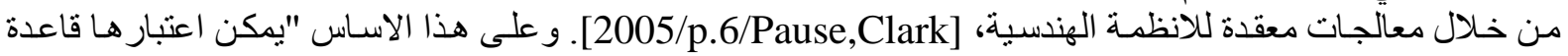

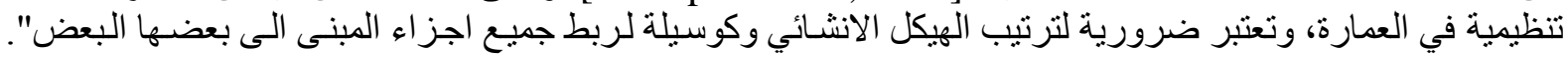

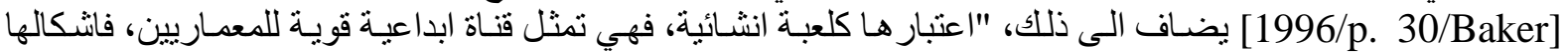

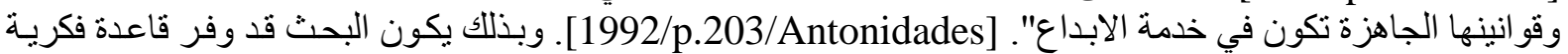
يمكن استثمار ها في توليد افكار النتاجات المعمارية خلال العملية التصميمية.

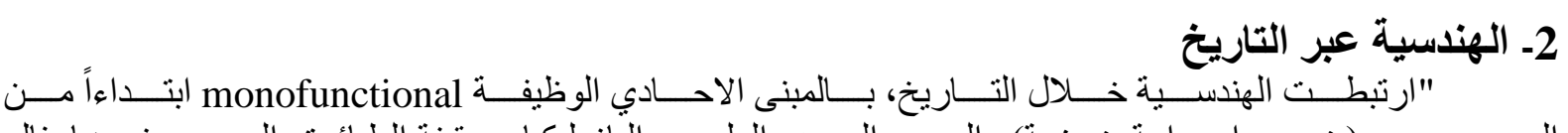

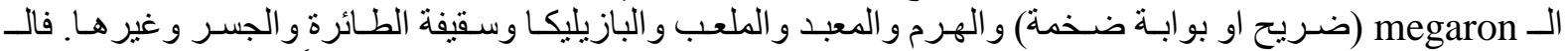
megaron

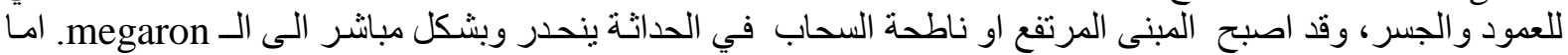

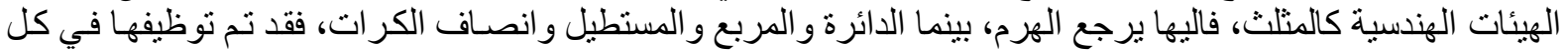

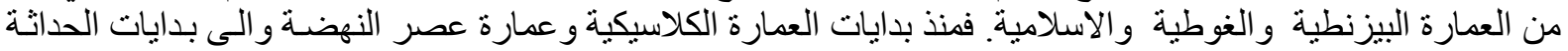

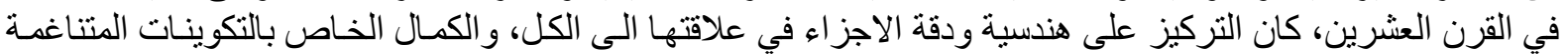

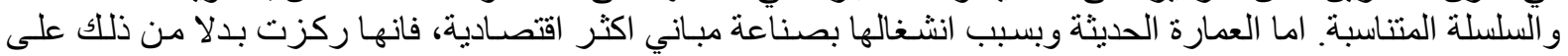

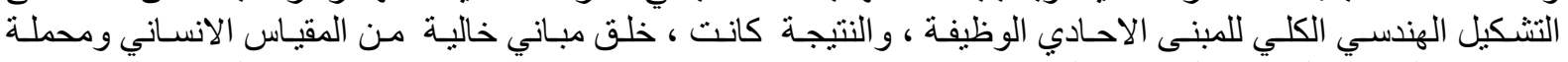

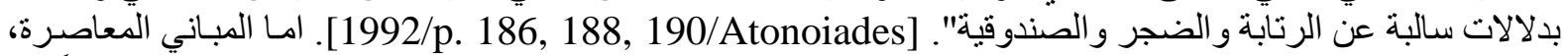

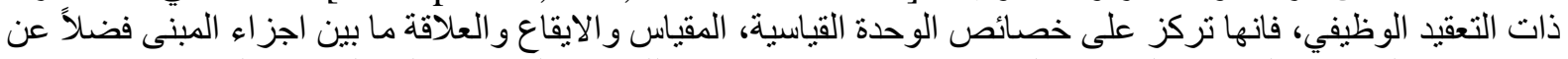

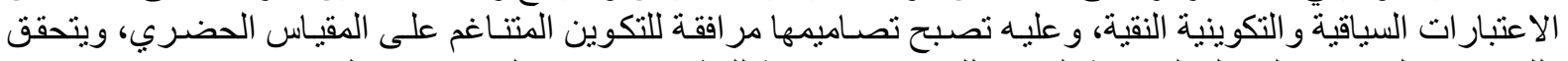

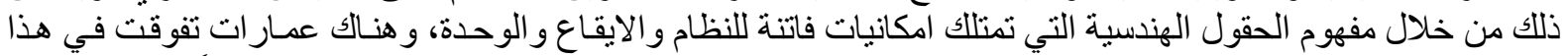

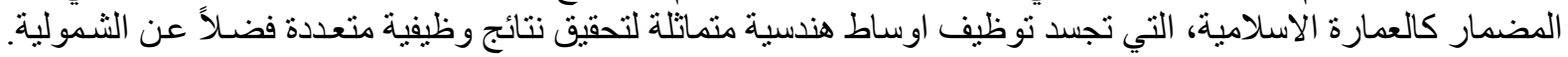

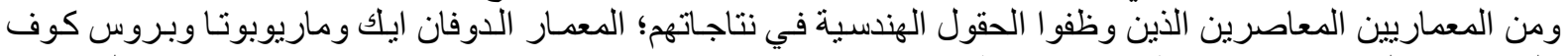

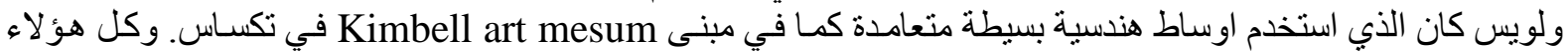

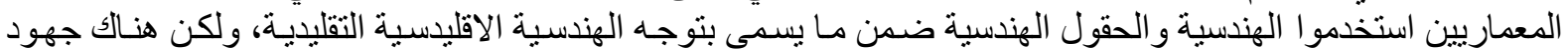

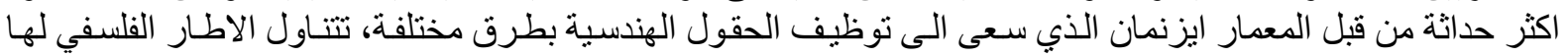

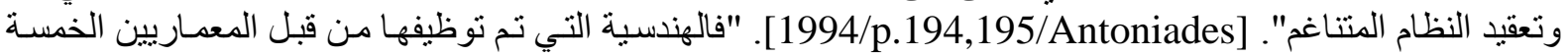

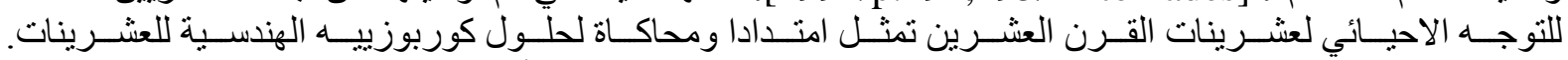
[1996/p.30/Baker]

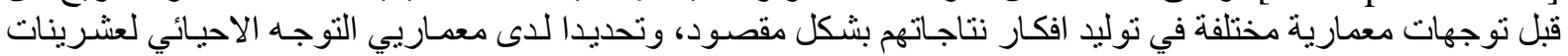

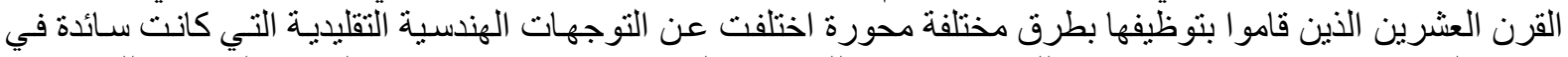

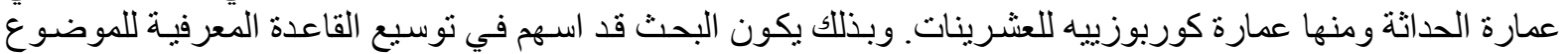

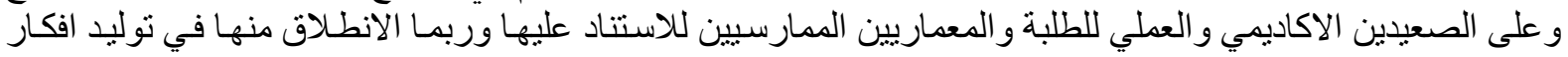

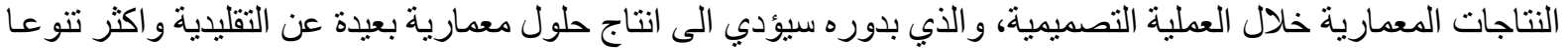

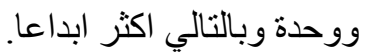

3ـ الهندسية كمولد للافكار المعمارية/الار اسـات السابقة قام البحث بتقويم و اقع المعرفة النظرية المتعلقة بالهندسية في الادبيات المعمارية و التي شملت:

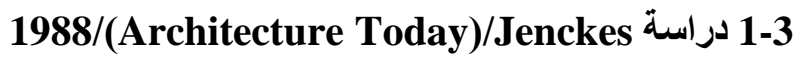

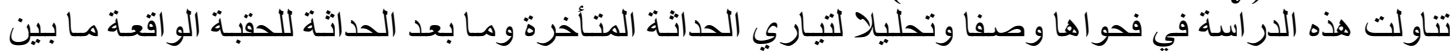
1960- 1990، وقد تميزت بكونها در اسة وصفية عامة اظهرت ارتباط التوجه الاحيائي لعشرينات القرن العشرين باحية العياء 
المبادئ الجمالية الهندسية لفيلات كوربوزييه للعشرينات، وذللك بتحوير ها باساليب مختلفة، و هذا يعني اعادة و لادة معتقدات

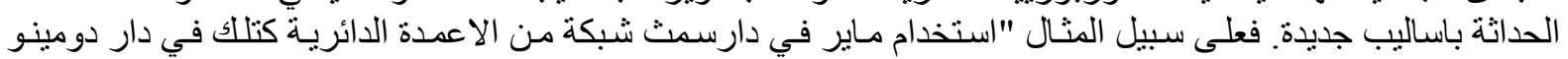

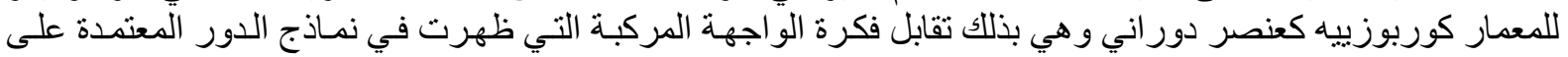

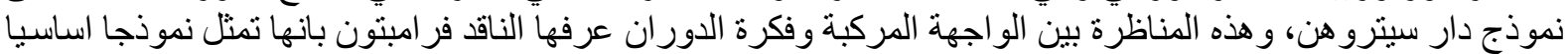

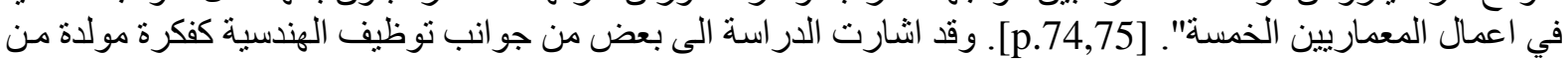

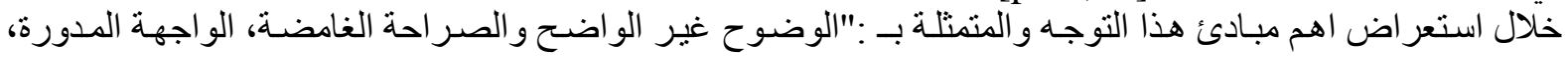

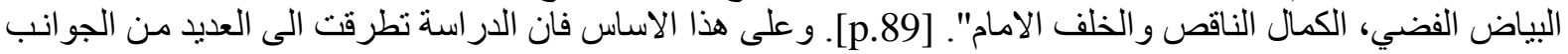

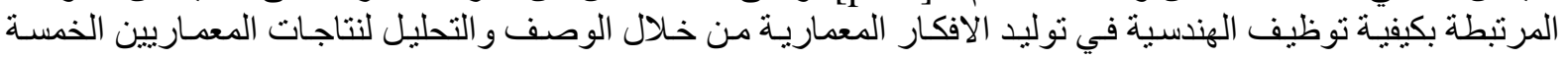

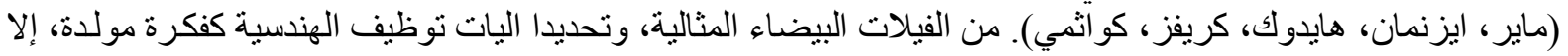

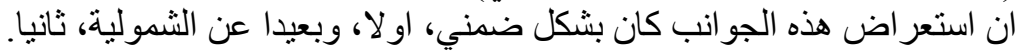

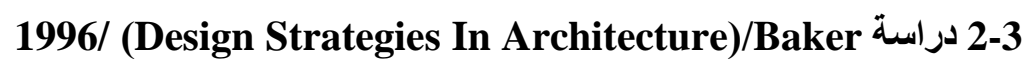

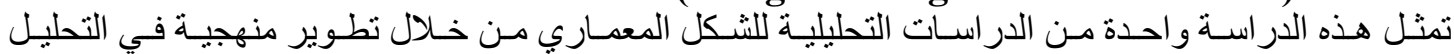

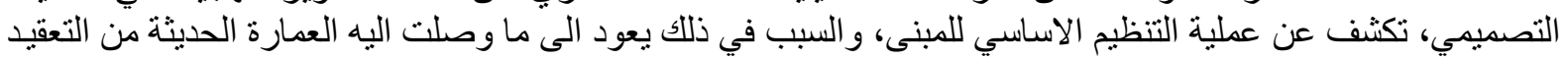

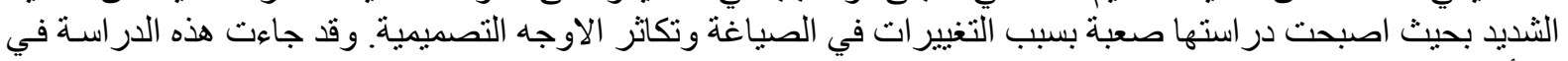

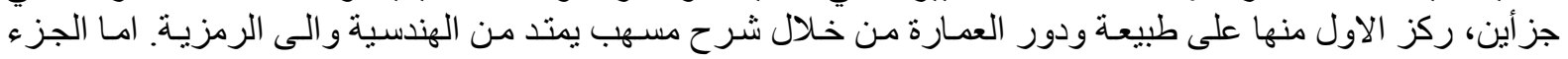

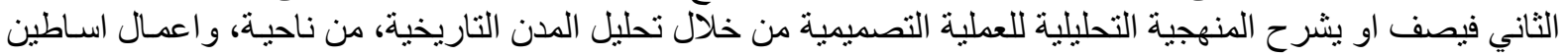

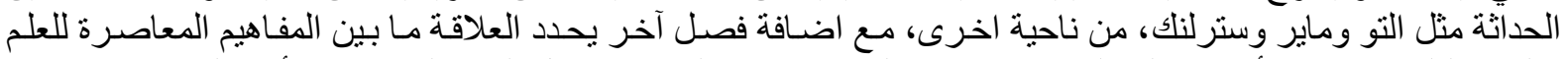

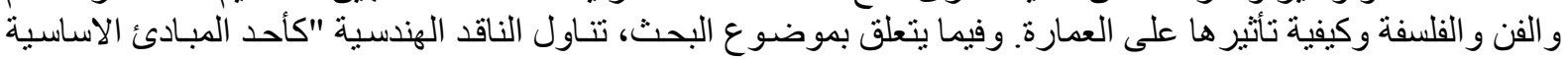

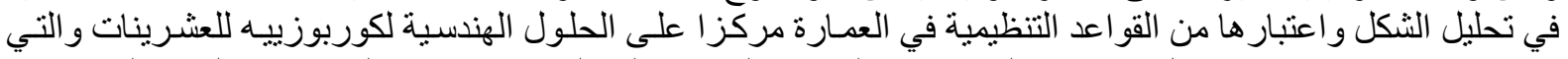

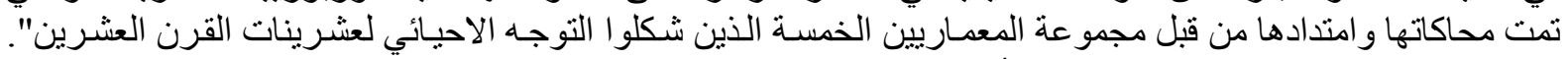

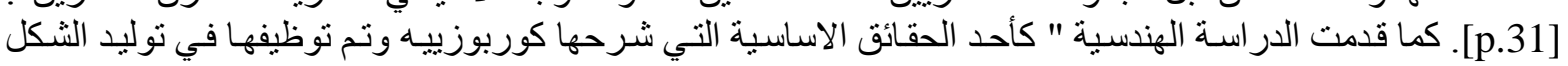

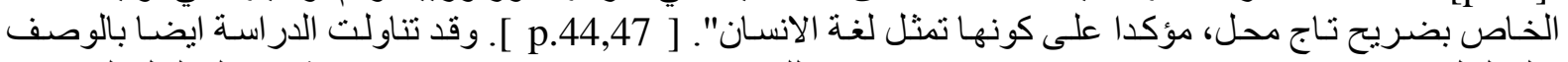

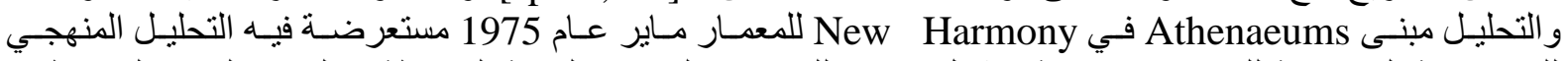

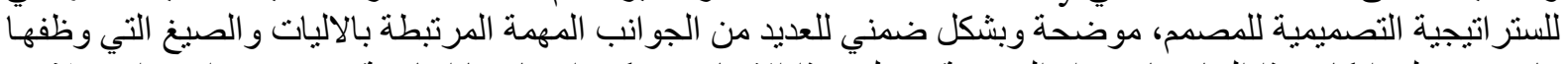

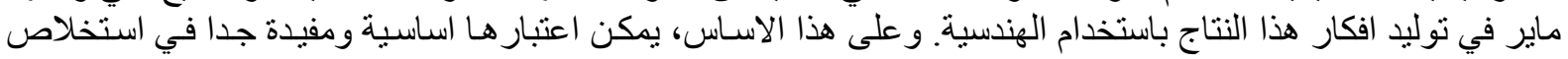

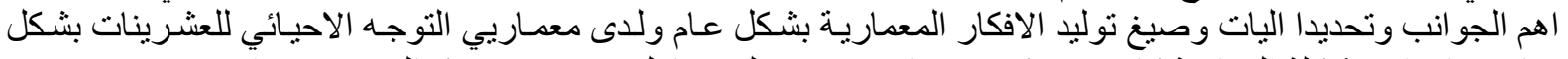

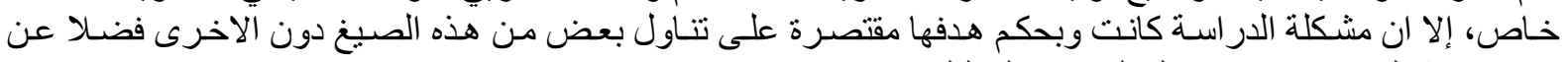
عرضها بشكل ضمني من خلال الوصف الوران التحليلي.

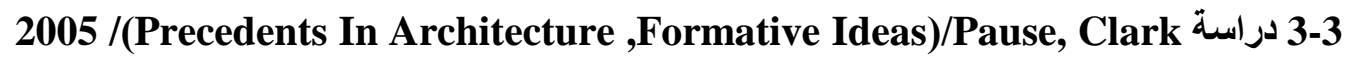

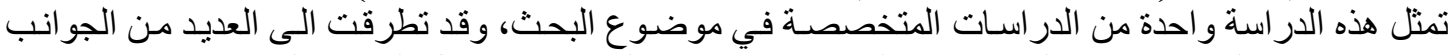

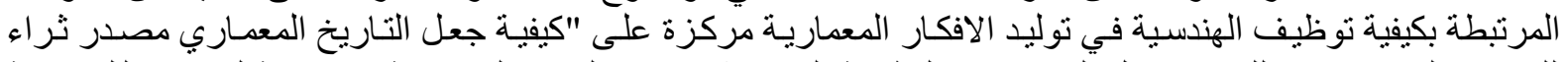

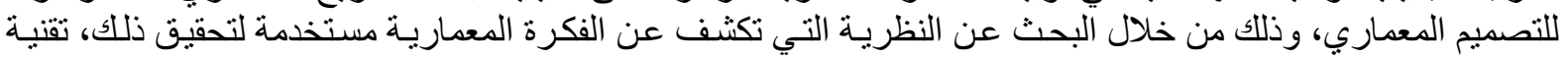

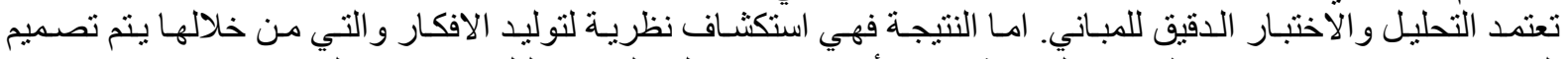

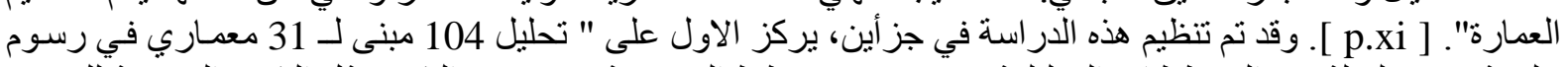

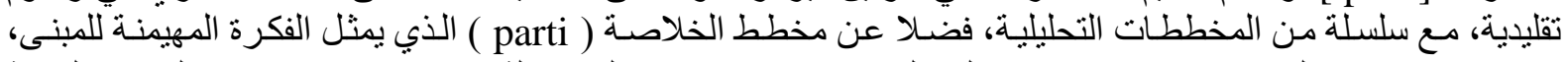

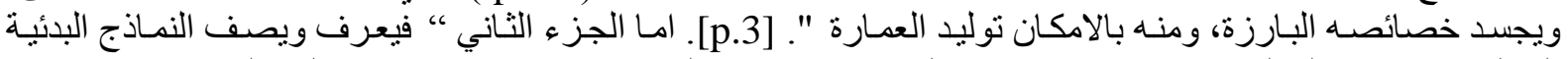

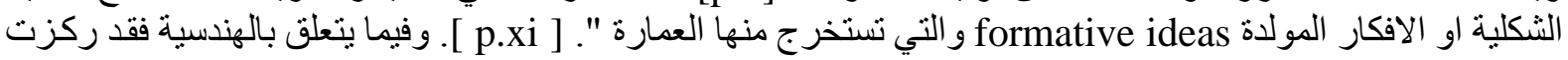

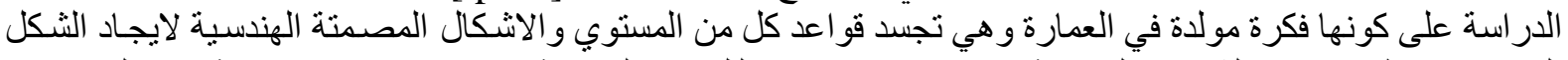

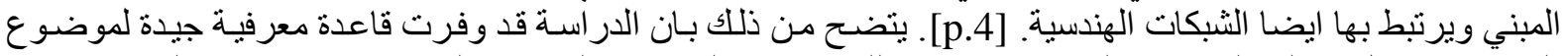

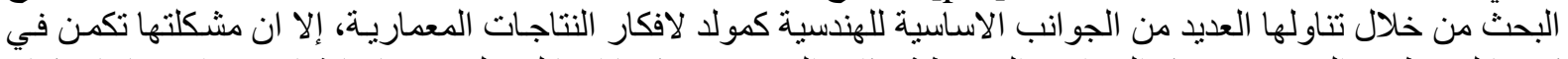

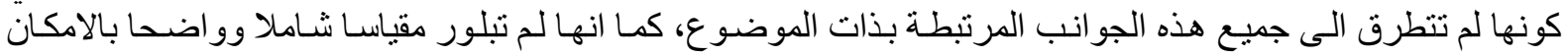

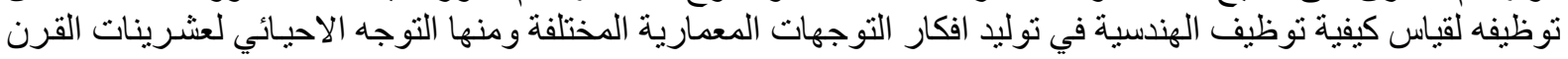

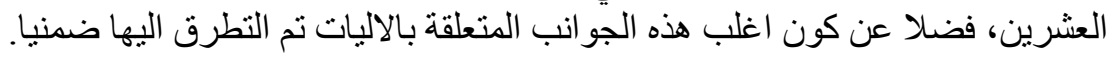

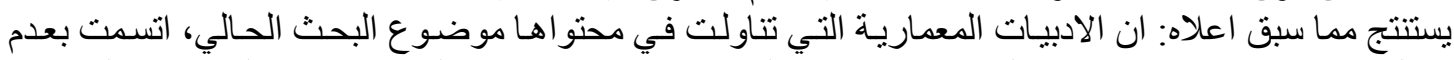

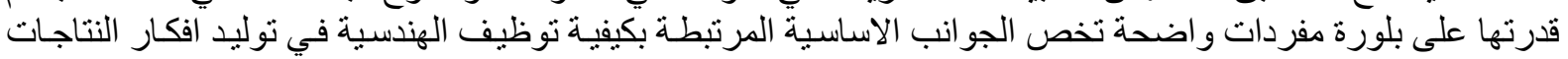

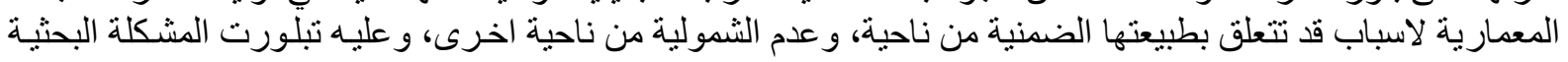


متمثلة بعدم وضوح المعرفة النظرية التي تحدد الجو انب الخاصة بكيفية توظيف الهندسية في توليد افكار نتاجـات معماريـة

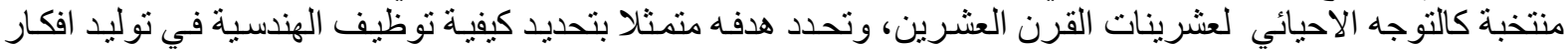

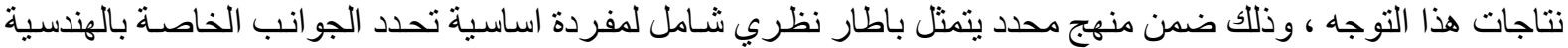

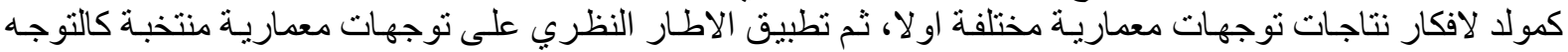

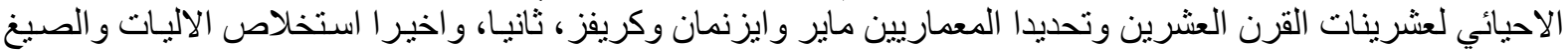

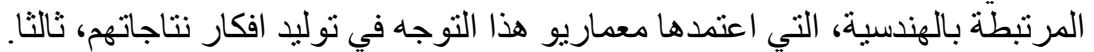

تناولت الهندسية كمولد للافكار المعماريـة جوانب مختلفة، تم فرز هـا من الدر اسـات السـابقة، وقد ارتبطت هذه

\section{4- الاطار النظري للهندسية كمولا للافكار المعمارية}

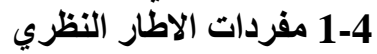

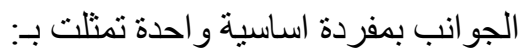

1-1-4 المفردة الاولى: اليات توليد الافكار المعمارية باستخدام الهندسية

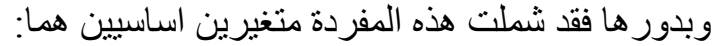

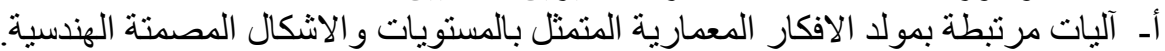

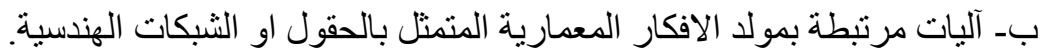

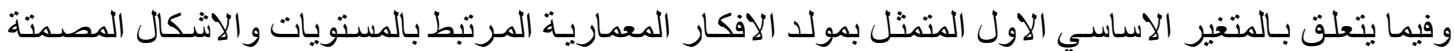

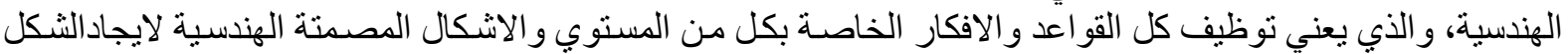

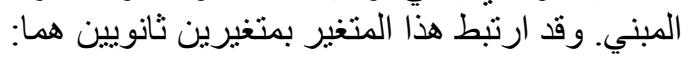

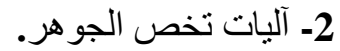

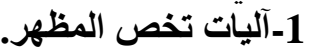
وفيما يتعلق بالاليات المرتبطة بالمظهر فقد شملت كل من:

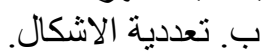

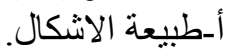

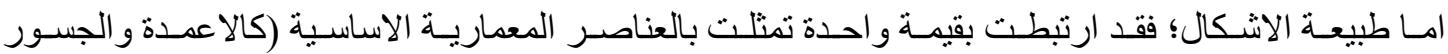

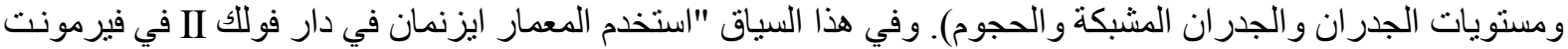

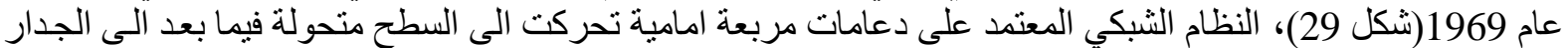

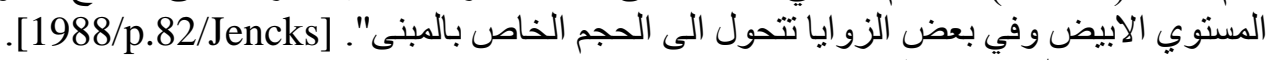

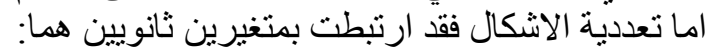
* ت اشكال هندسية متعددة.

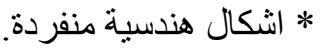

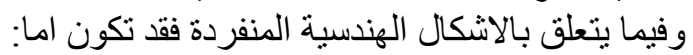

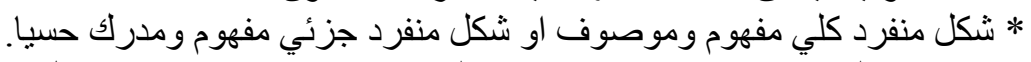

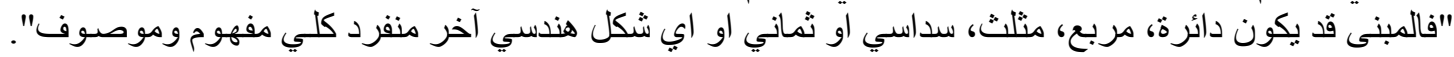

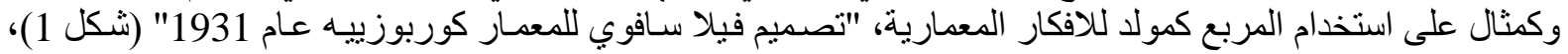

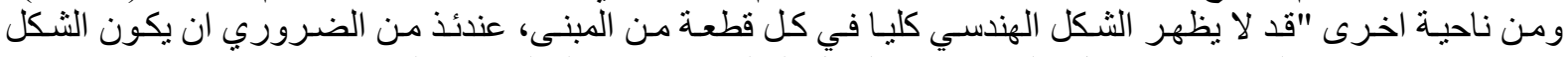

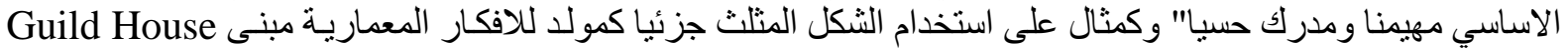

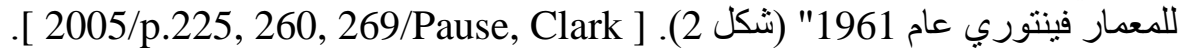
اما فيما يتعلق بالاشكال الهندسية المتعددة فقد ارتبطت بقيم اخرى تراوحت ما بين الابعاد و الهيئة و المألوفيـة فهي

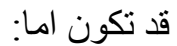
* متساوية الابعاد او مختلفة الابعاد. * مشتابهة الهيئة او مختلفة الهيئة.

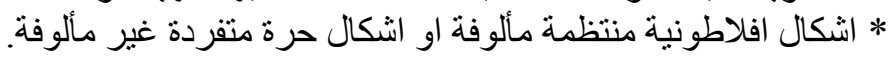

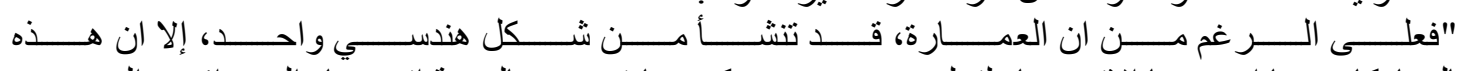

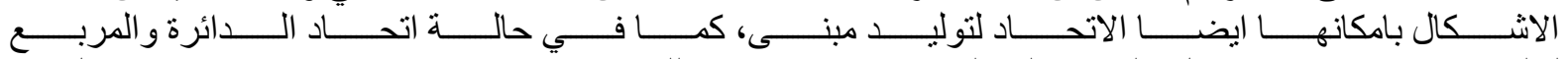

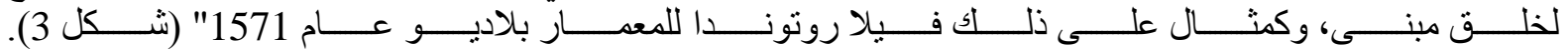

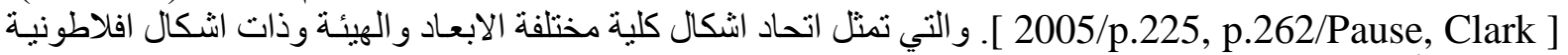

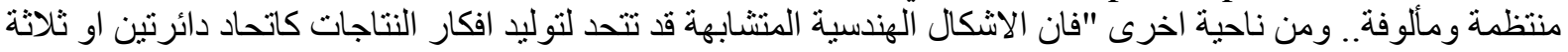

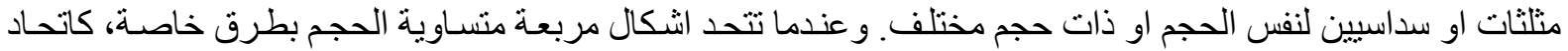

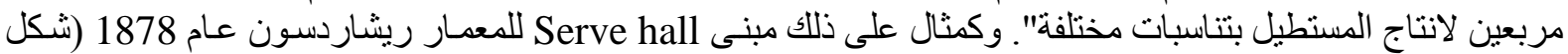

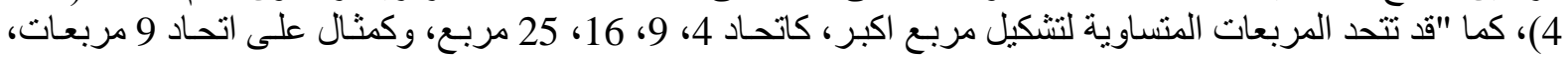

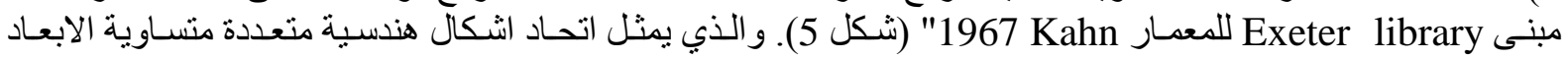




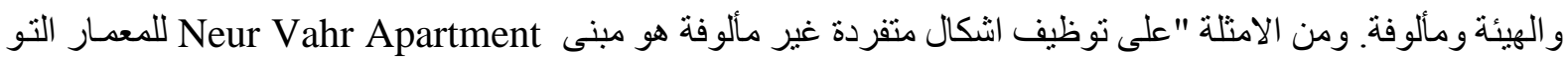

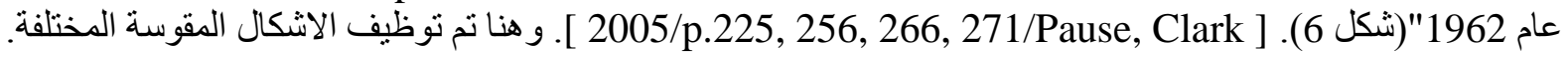

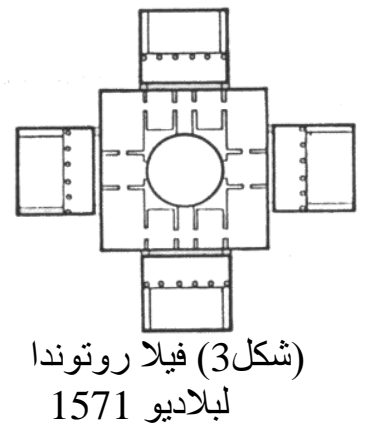

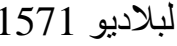

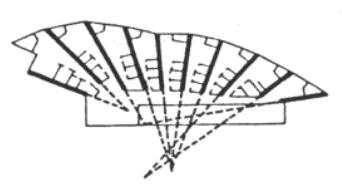

Neur Apartment (شكل6) لالتو 1962

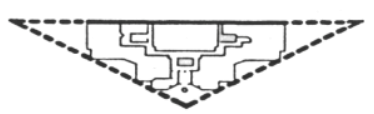

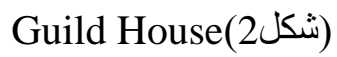

لفينتوري 1961

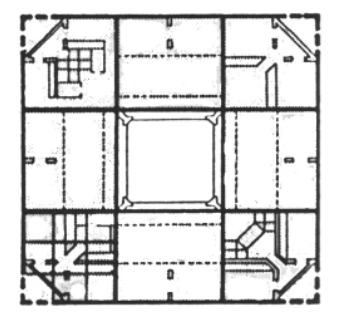

Exeter Library (شكل5 (شكل)

1967 لكان

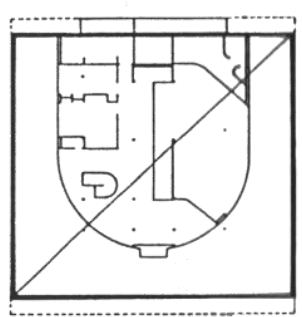

(شكل 1)فيلا سافوي

لكوربوزييه 1931

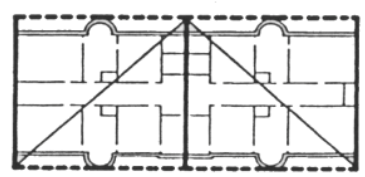

Serve Hall (شكل4)

لريشار دسون 1878

اما فيما يتعلق بالاليات المرتبطة بالجوهر فقد شملت كل من:

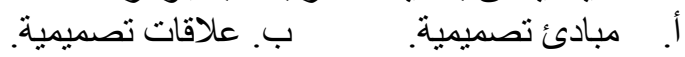

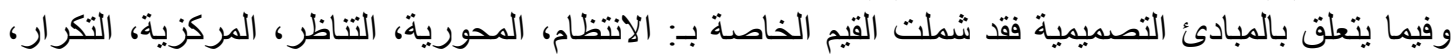

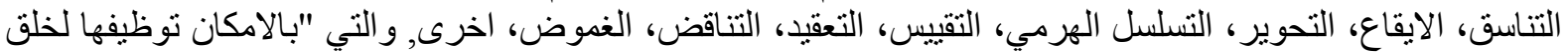

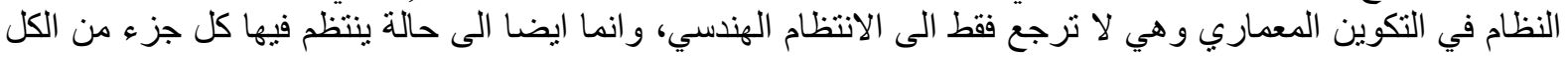

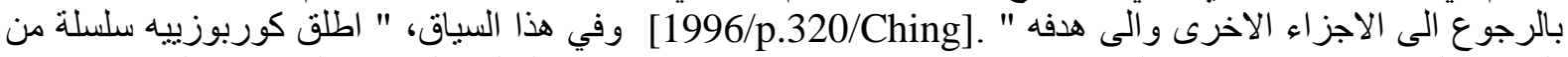

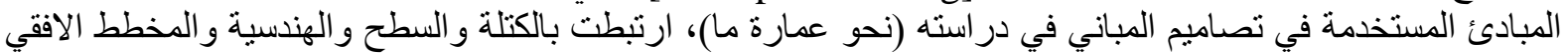

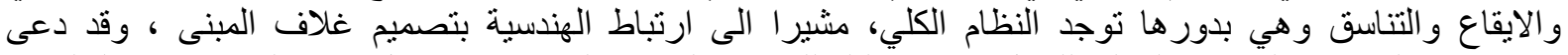

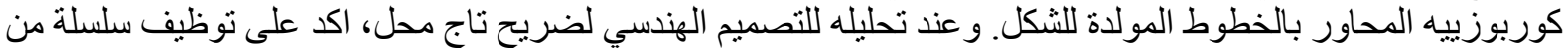

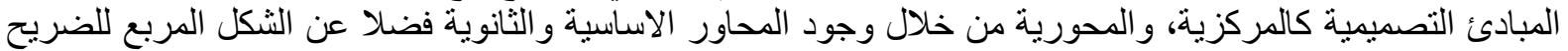

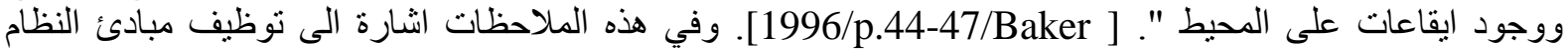
التصميمية في توليد افكار نتاجات معمارية تخضع للهندسية المركزية أو الهندسية الساكنة.

اما فيما يتعلق بالعلاقات التصميمية فقد شملت القيم الخاصة بـ: 1- معالجات شكلية Formal manipulations وبدور ها فقد ارتبطت فئست بقيمتين: * اتحاد Combination. 2- معالجات تكوينية Composional manipulation وقد ارتبطت بقيمة واحدة:

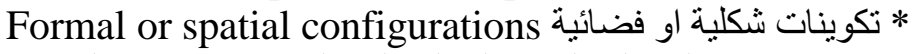

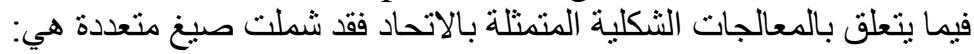

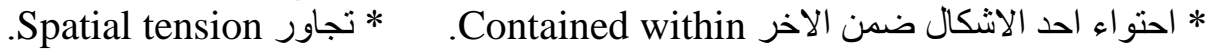

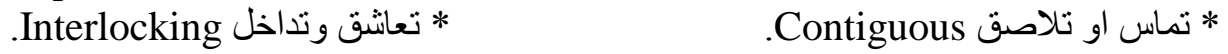

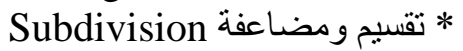
* انفصال وتر ابط بعنصر رابط Separation and linked by a common element. 


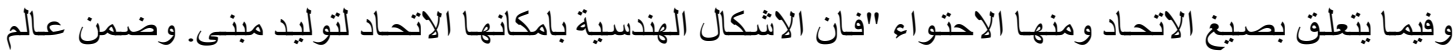

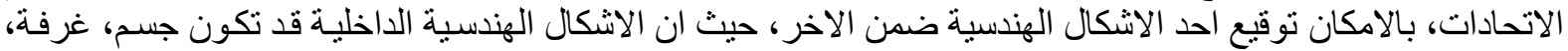

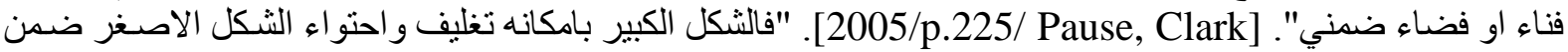

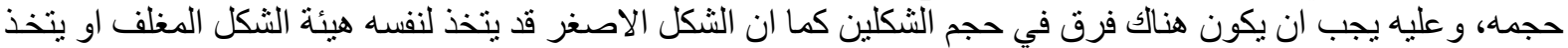

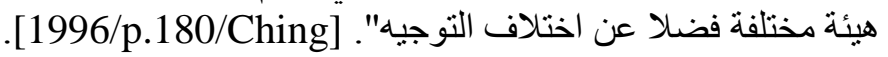

امـاصيغة الاتحـاد الاخرى المتمنلـة بالتجاور "فتعتمد على تقارب الاشكال و اشتر اكها بخاصية بصرية عامـة كالميئة و اللون و المادة". [1996/p.56/Ching]

$$
\begin{aligned}
& \text { وفيما يتعلق بصيغة التماس او التلاصق للاشكال الهندسية والتي تر اوحت ما بين: } \\
& \text { * تماس خطي (حافة الى حافة) تماس سطحي (سطح الى سطح). *ماس حافة الى سطح. }
\end{aligned}
$$

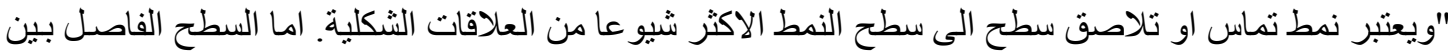

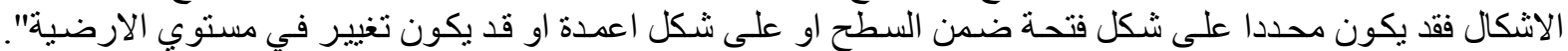

.[1996/p.56, 184/Ching ]

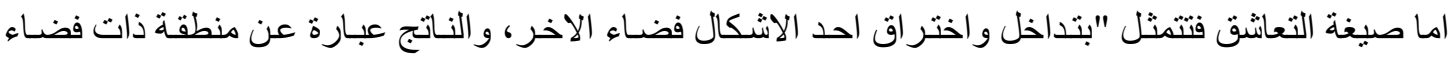

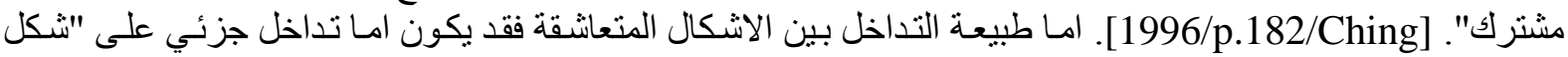

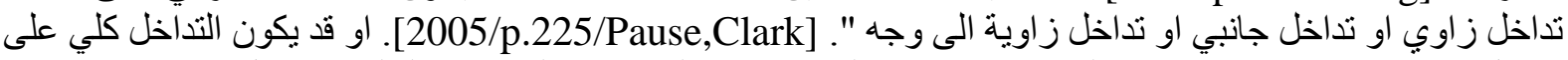

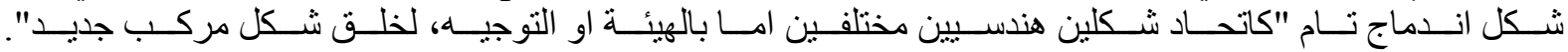

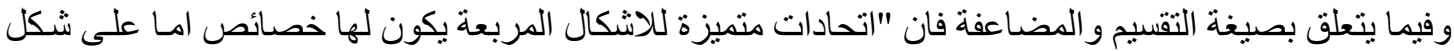

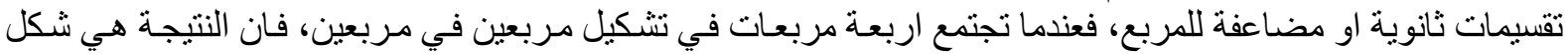

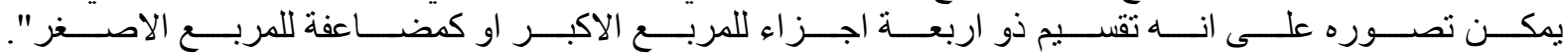

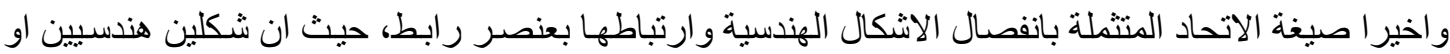

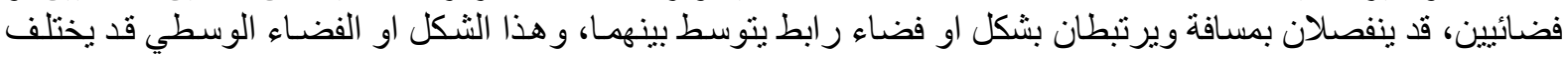

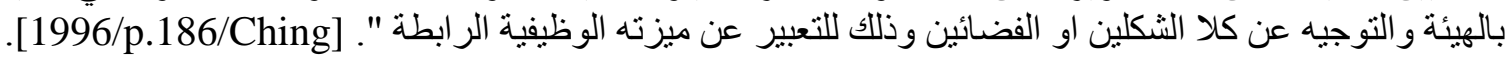

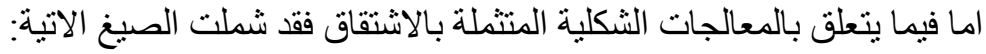

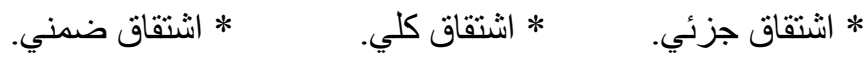

وفيما يتعلق بصيغة الاشتقاق الجزئي فقد ارتبطت "بامكانية اشتقاق اشكال هندسية باستخدام اجزاء من الهيئات الهات

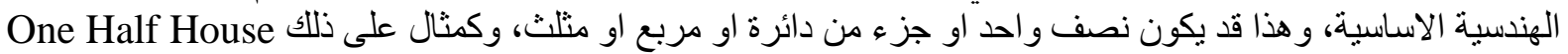

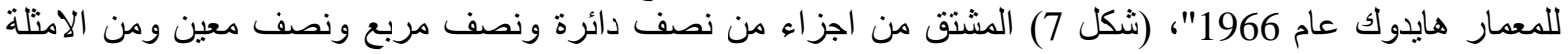

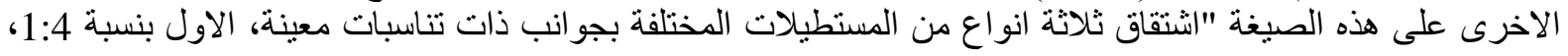

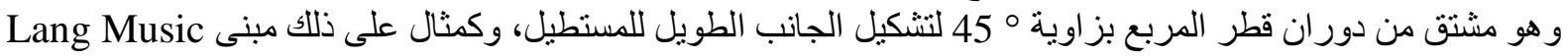

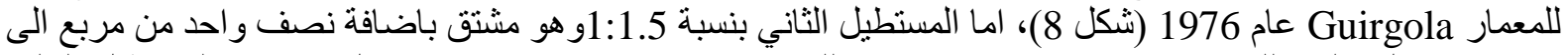

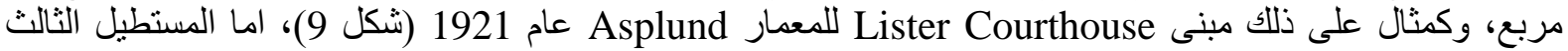
فبنسبة 1:1.6 وهو مستطيل الوسط الذهبي، وهو مشتق من دوران قطر نصف مربع لتشكيل الجانب الكبير للمستطيل،

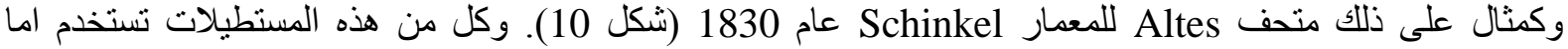
لمفردها او في اتحادات لتشكيل مباني او اجز اء مباني". [2005/p.226, 268, 269/Pause, Clark]. 

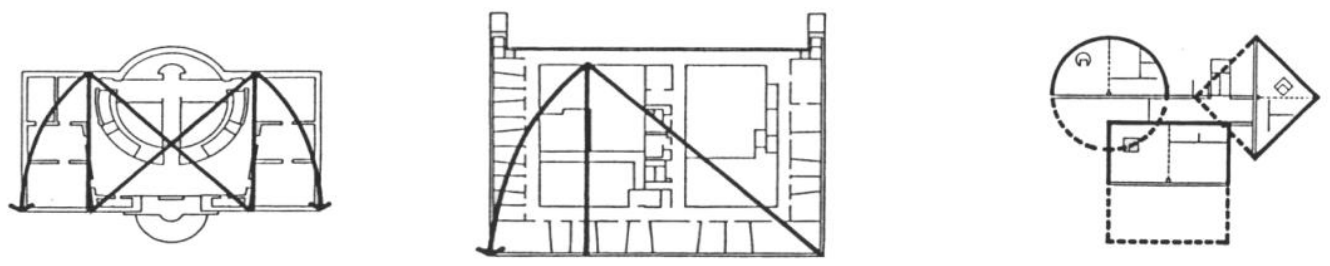

L.Courthouse شكل9) مبنى)

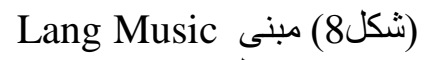

1921 لاشبلنين

لكويركو لا 1976

One Half House(شكل)

لهايدوك 1966

اما فيما يتعلق بصيغة الاشتقاق الكلي فنتمثل "بانتقاق اشكال هندسية من اشكال متكاملة كاشتقاق المستطيل بنسبة

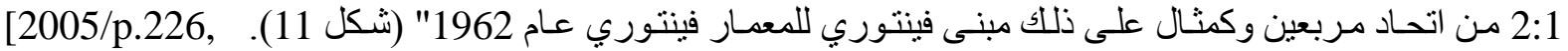

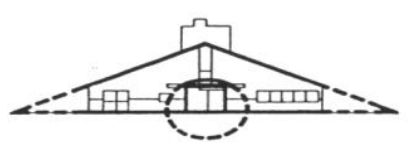

(شكل12) و اجهة دار فانا فينتوري

لفنتوري 1962

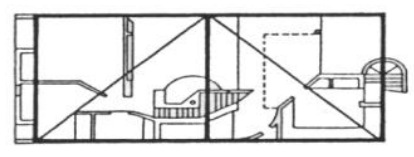

(شكل) دار فانا فينتوري

لفنتوري 1962

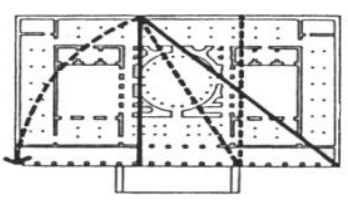

Altes شكل(10)متحف)

1830 لشنكل)

و اخيرا صيغة الاشتقاق الضمني الذي يشمل "تضمين شكل هندسي اكبر بنقاط تقع ضمن التشكيل المعماري

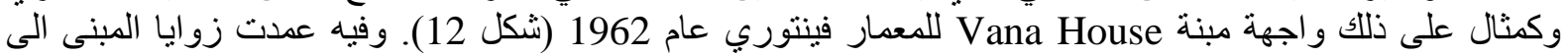

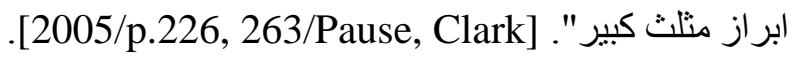

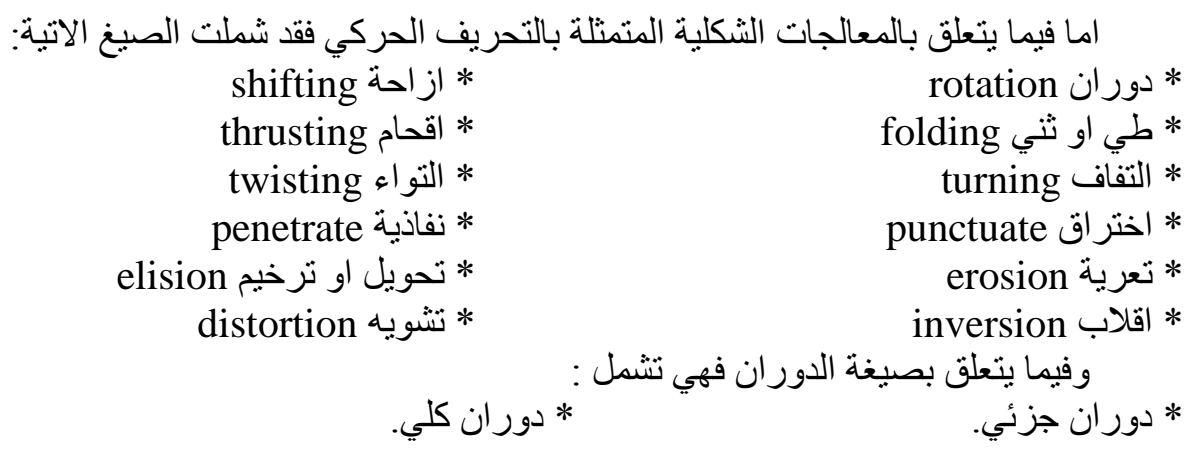

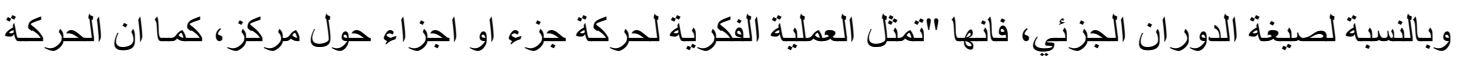

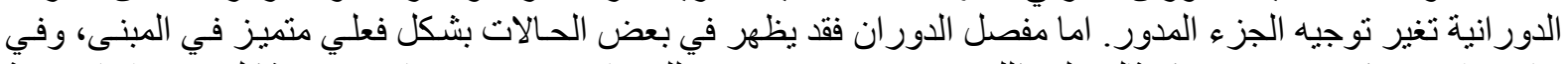

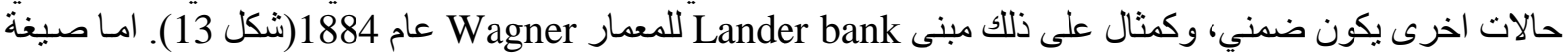

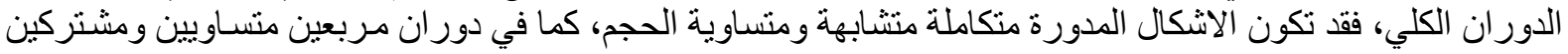

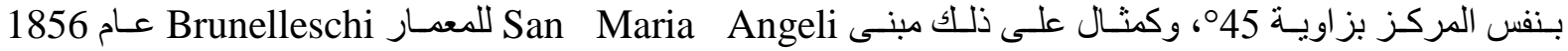
(شكل 14). كما قد تكون الاشكال المدورة متكاملة متشابهة ومختلفة الحجم او مختلفة التشكيل وقد يكون التر ابط بينها قليلا

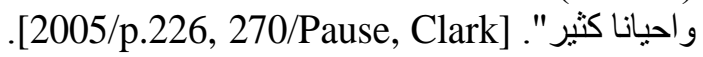

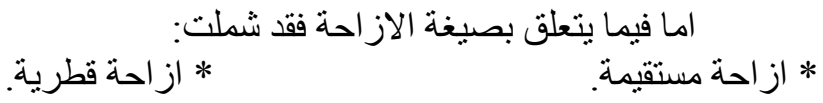




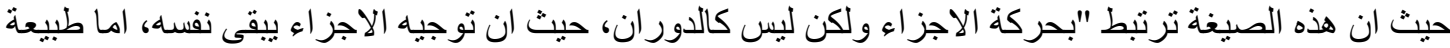

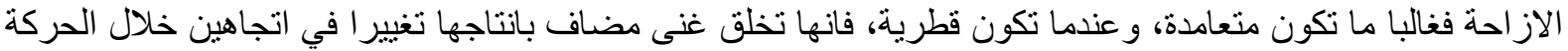

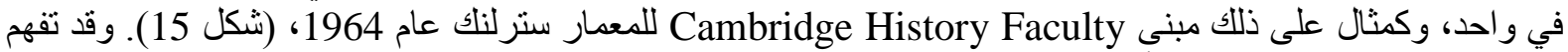
الازاحة على انها انزلاق لجزئل أين واحد ضد الاخر، وبحصول ذلك يتكون فضاء ما بين الاجزاء المزاحة لمعادلة

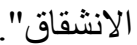

[2005/p.226, 270/Pause, Clark]
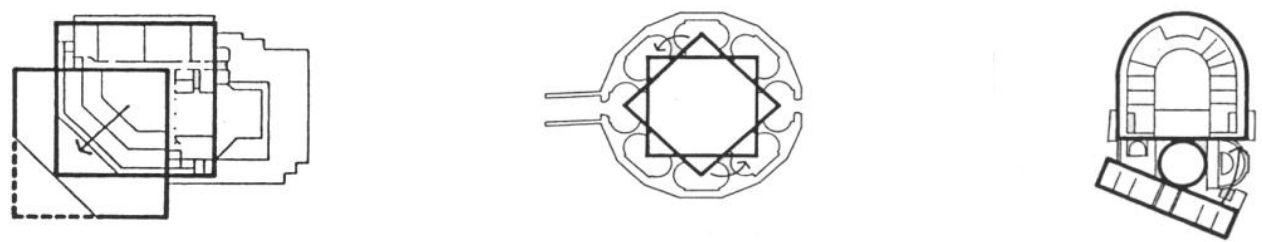
C.H.Faculty شكل15) مبنى (شكر)
S.M.Angeli شكل114) مبنى

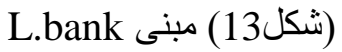
لسترلنك 1964
لبرونيلسي 1856 منسى 185
لو اكنر 1884

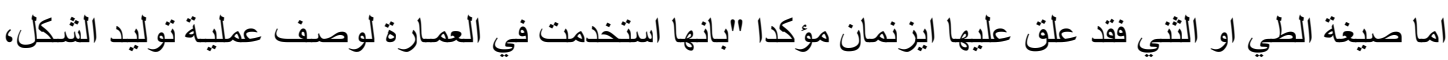

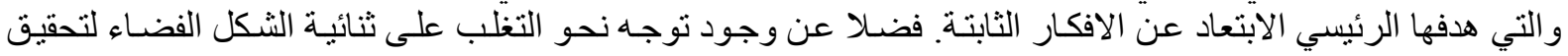

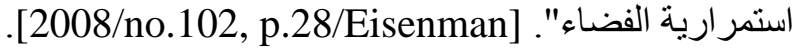

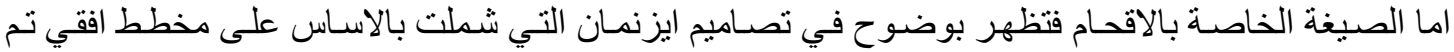

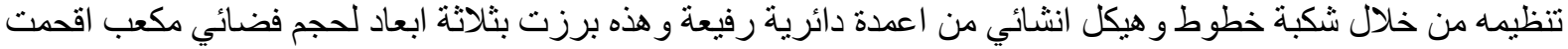

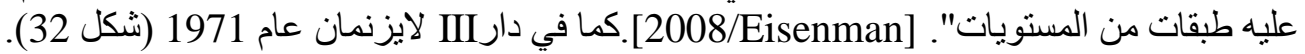

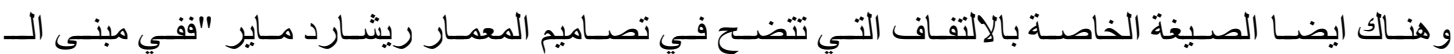

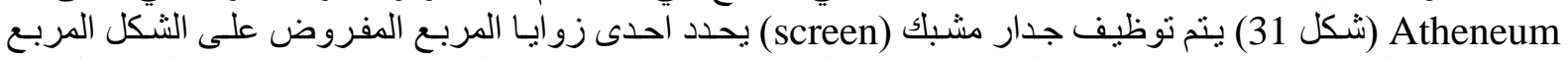

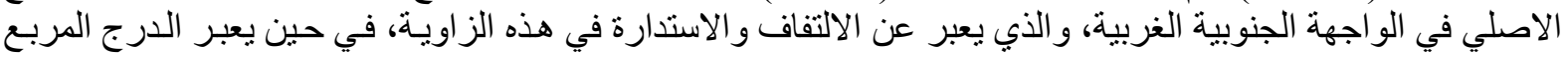

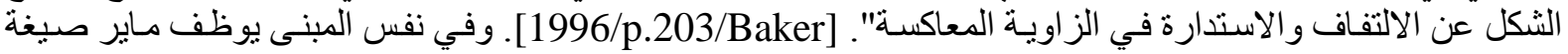

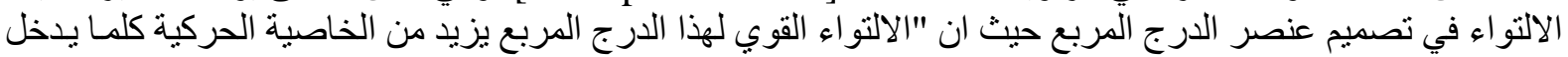

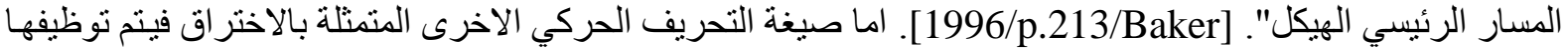

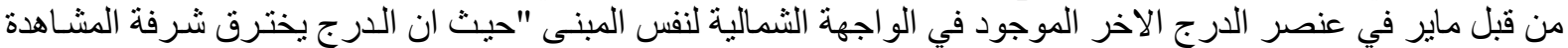

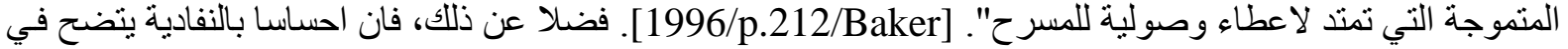

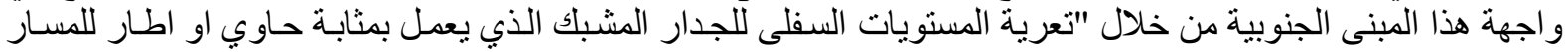

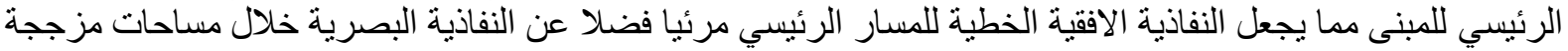

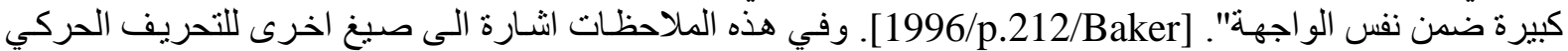
تتمثل بالنفاذية و التعرية.

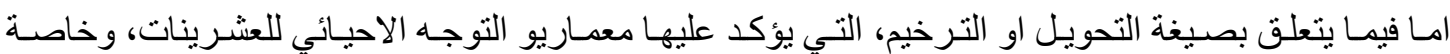

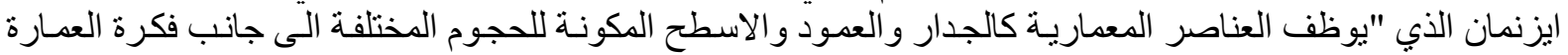

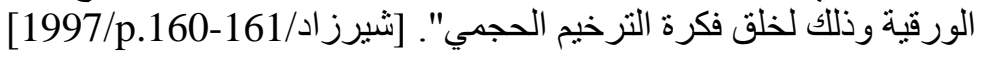

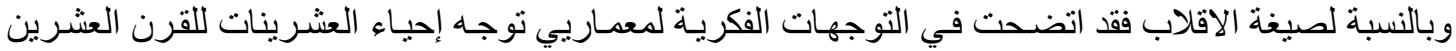

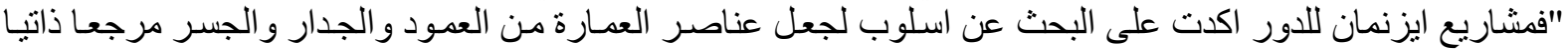

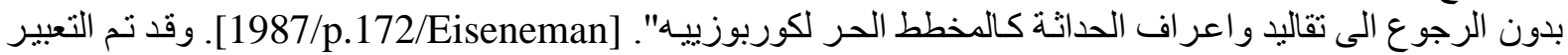

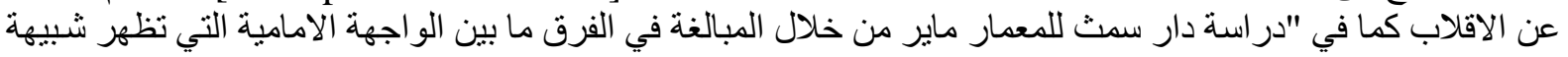

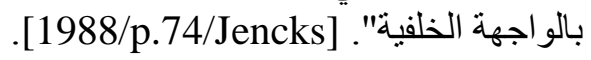




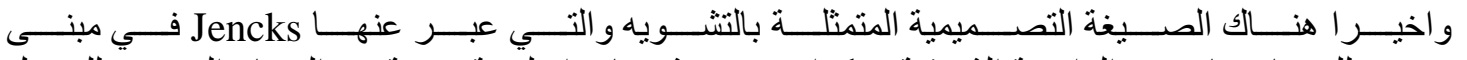

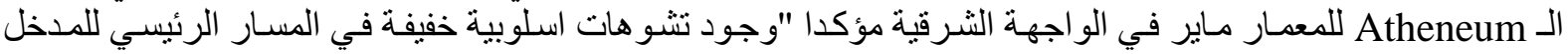

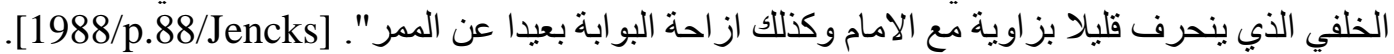

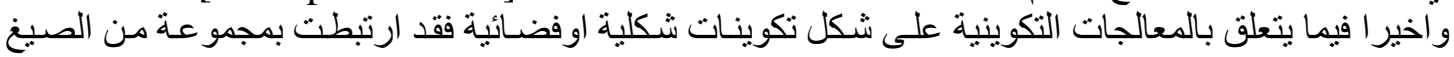

$$
\begin{aligned}
& \text { * حلزونية } \\
& \text { * خطية خلزونة اندية } \\
& \text { * شبكية }
\end{aligned}
$$

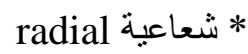
التكوينية:

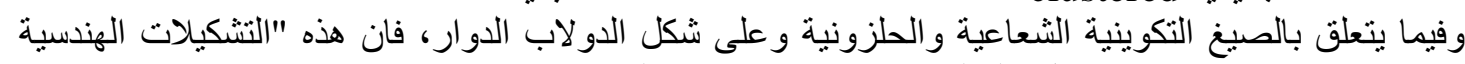

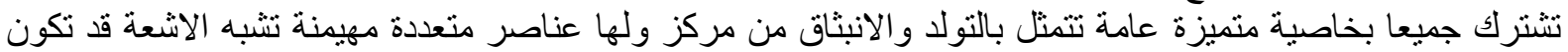

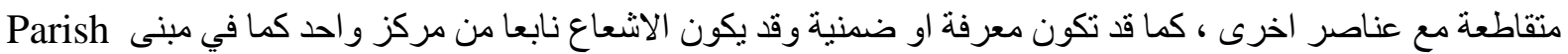
center

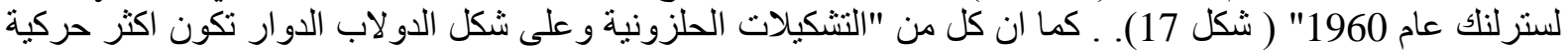

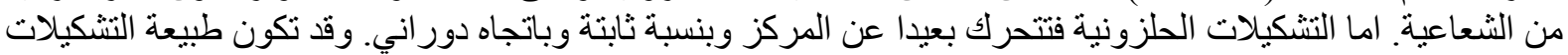

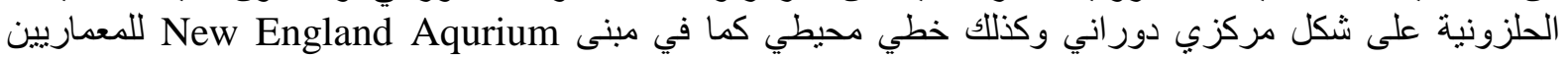
Cambridge Associates

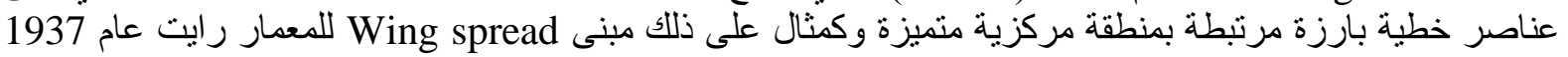

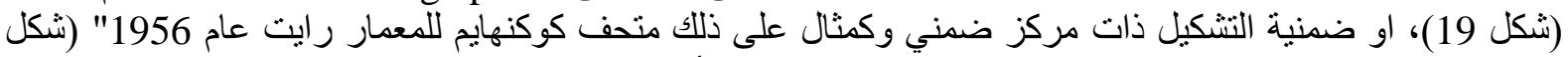

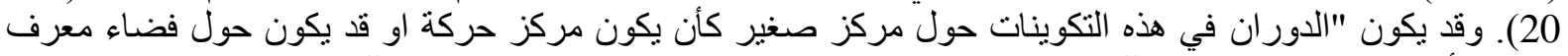

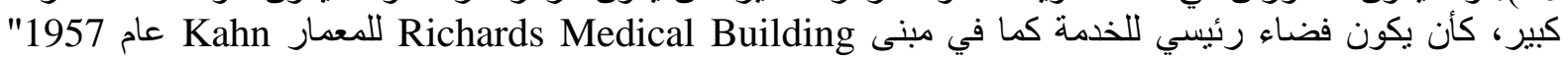

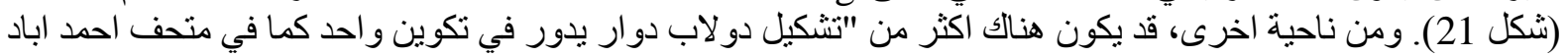
في الهند للمعمار كوربوزييه عام 1957"(شكل 22)، فهناك تشكيلين، الاول ضمن المعرض الرئين فئيسي والثناني للمبنى

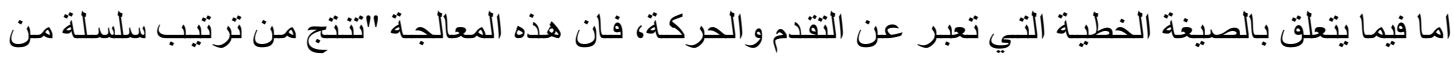

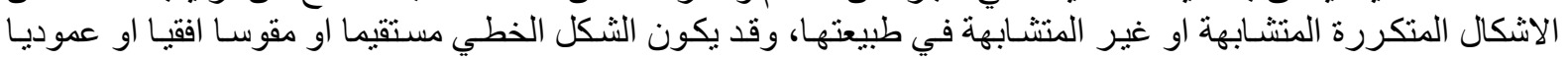

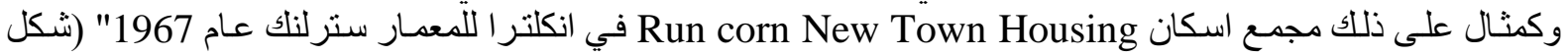
.[1996/p.60-61/Ching] .)(23

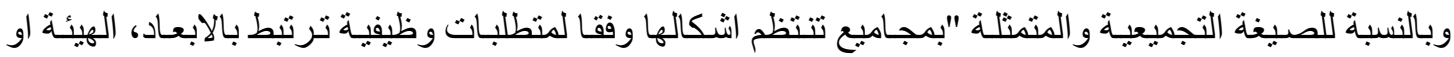

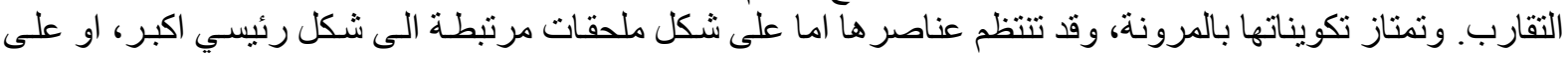

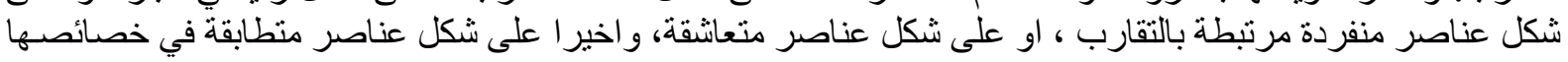

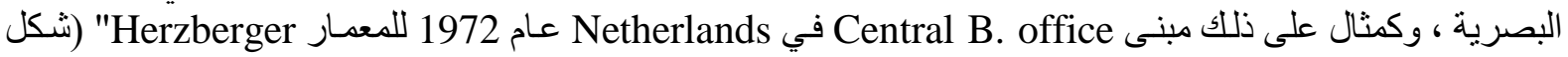

.[1996/p.66-69/Ching].).24

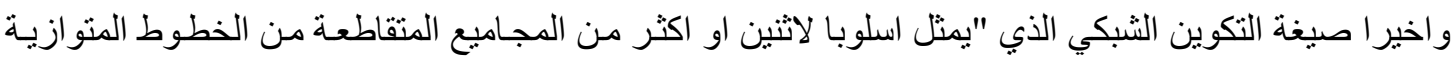

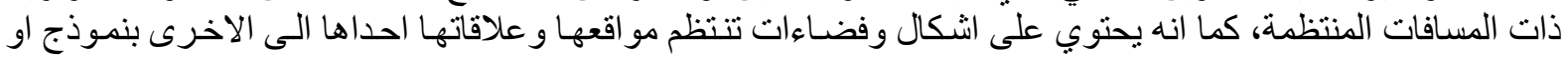

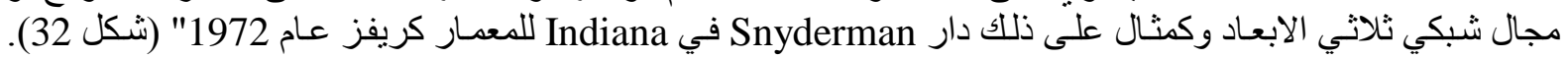

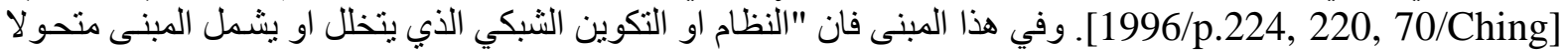

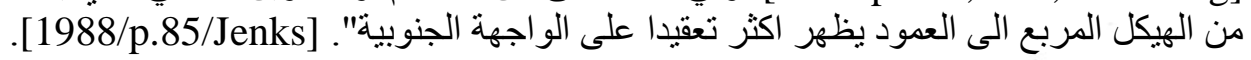

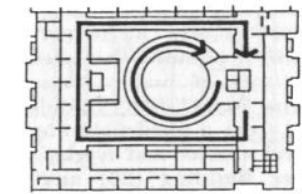

N.E.Aqurium(شكل18) مبنى (18) لمؤسسة كامبرج 1962

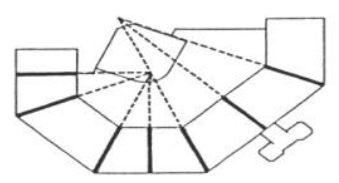

Flory (شكل17) مبنى (نال) لالتو 1960

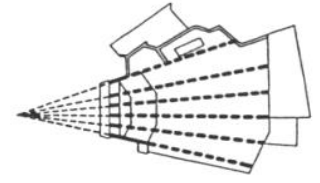

(شكل16) مبنى.Parish C لالتو 1960 


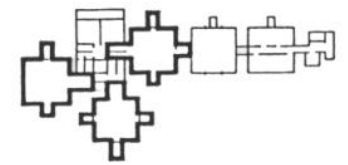

(شكل21) مختبرات ريشاردز الطبية لكان 1957

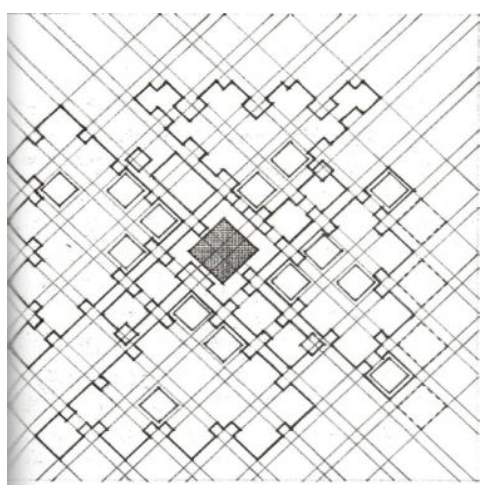

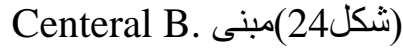
لهرتزبركر

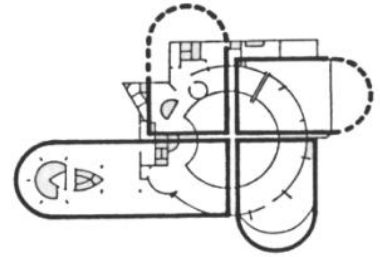

(شكل20) متحف كو كنهايم لر ايت 1956

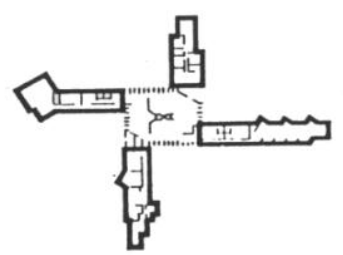

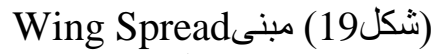

لر ايت

اما فيما يتعلق بالمتغير الاساسي الثاني المتمثل بمولد الافكار المعمارية المرتبط بالثبكات الهندسية

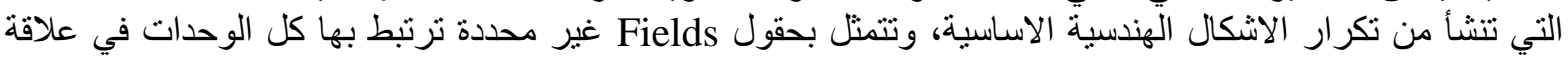

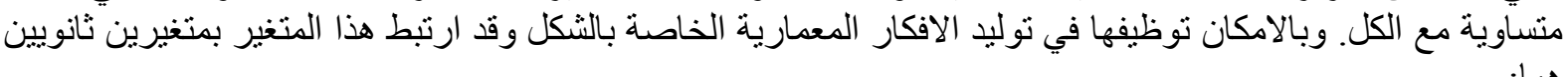

$$
\begin{aligned}
& \text { 2- اليات تخص الجوهر. }
\end{aligned}
$$

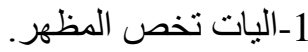

$$
\begin{aligned}
& \text { وفيما يتعلق بالاليات المرتبطة بالمظهر فقد شملت القيم الاتية: }
\end{aligned}
$$

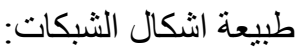

$$
\begin{aligned}
& \text { أـ من ناحية الابعاد. بـ من ناحية الاتجاه. ج- من ناحية تعددية السلاسل. }
\end{aligned}
$$

وفيما يتعلق بطبيعة اشكال الثبكات من ناحية الابعاد، "فالمسافات بين خطوط الثبكة بالامكان ان تكون منسـاوية

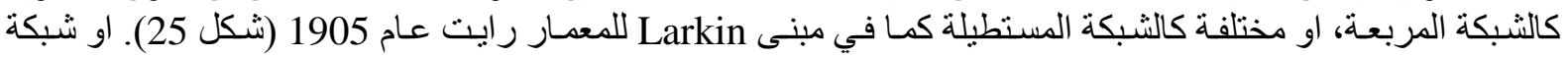

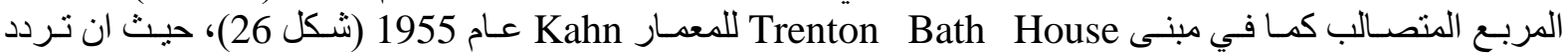

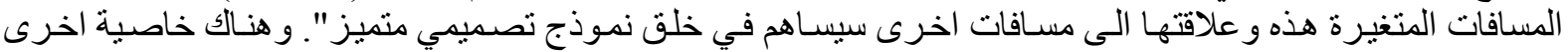

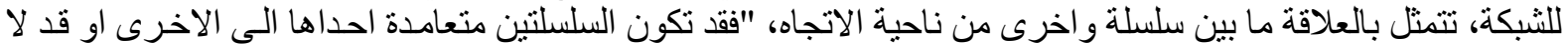

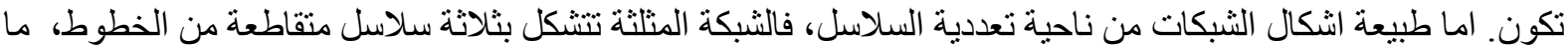
في مبنى National Gallary للمعمار Pei, 1975" (شكل20127). [2005/p.227,272,273/Pause,Clark)

$$
\begin{aligned}
& \text { اما فيما يتعلق بالاليات المرتبطة بالجو هر فقد شملت علاقات تصميمية على شكل: } \\
& \text { معالجات شكلية و التي بدور ها ارتبطت بقيمتين هما: * اتحاد تحريف حركي }
\end{aligned}
$$




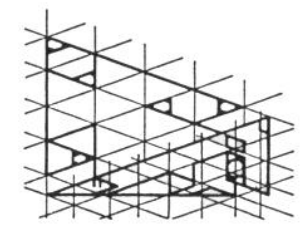

National G.شكل) مبنى (شنى) لبي 1975

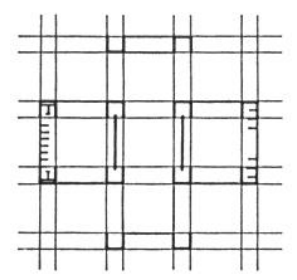

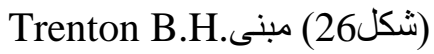
لكان 1955

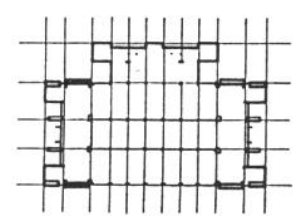

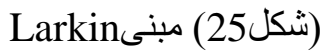

لر ايت 1905

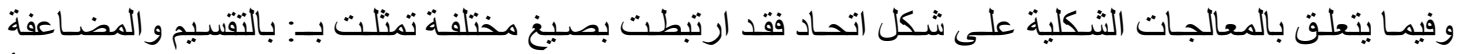

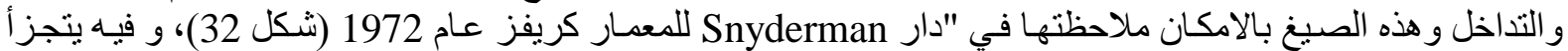

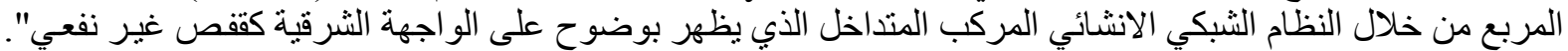
1988/p.84, 85/Jencks]

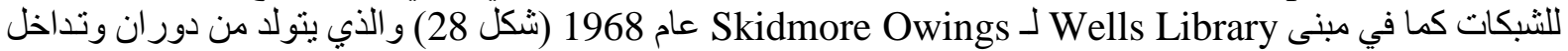

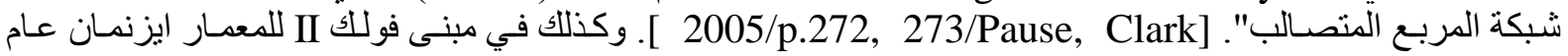

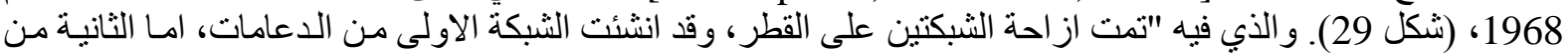

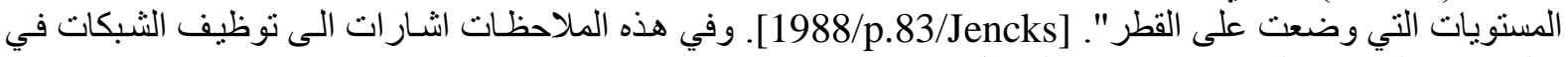
توليد افكار النتاجات المعمارية. يوضح الجدول (4-1)

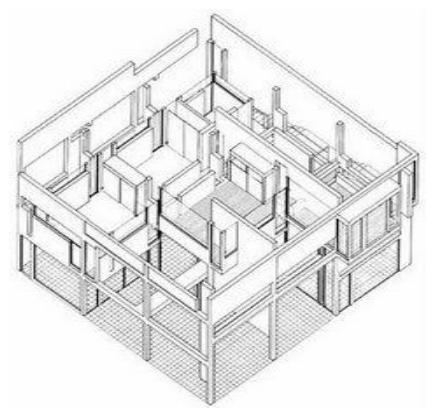

(شكل29) دار فولك II لايزنمان

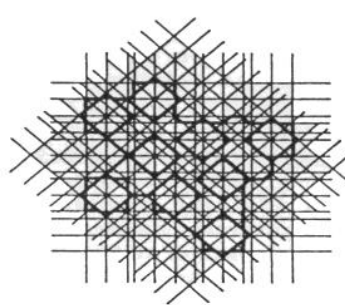

Wells L.شكل) مبنى (ش) 1968 Skidmore O. J

[2005/p.260-273/Pause,Clark] (1-22,25-28) مصادر الاشكال: الاشكال

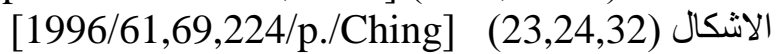
[1988/p.83/Jencks]

الشكل (29) (29)

جدول (1-1): القيم الممكنة للمفردة المتمثلة، بآليات توليد الافكار المعمارية باستخدام الهندية. المصدر: الباحث

\begin{tabular}{|c|c|c|c|c|c|c|}
\hline القيم الممكنة & \multicolumn{5}{|c|}{ المتغيرات الفرعية } & المفردة اسم \\
\hline عناصر معمارية اساسية (اعدة، جسور، جدران، حجوم) & \multicolumn{3}{|c|}{ طبيعة الاشكال } & \multirow{8}{*}{ 舟 } & \multirow{8}{*}{ 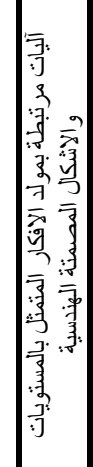 } & \\
\hline شكل منفرد كلي مفهو وموصوف & مضلعات، & اثكال هنسية منفردة (مربع د & & & & $\exists$ \\
\hline شكل منفر د جزني مفهو ومدرك حسيا & & & & & & $y_{7}^{2}$ \\
\hline متساوية الابعاد & من ناحية & \multirow{5}{*}{ اشكال هنسية متعددة: } & . & & & 3 \\
\hline مختلفة الابعاد & الابعاد & & 霩 & & & 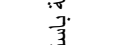 \\
\hline متشابهة الهيئة & \multirow{2}{*}{ من الهيئة } & & & & & $\frac{1}{2}$ \\
\hline مختلفة الهيئة & & & & & & 雪 \\
\hline اثشكال افلاطو نية مألو فة منتظمة & من ناحبة & & & & & \\
\hline
\end{tabular}




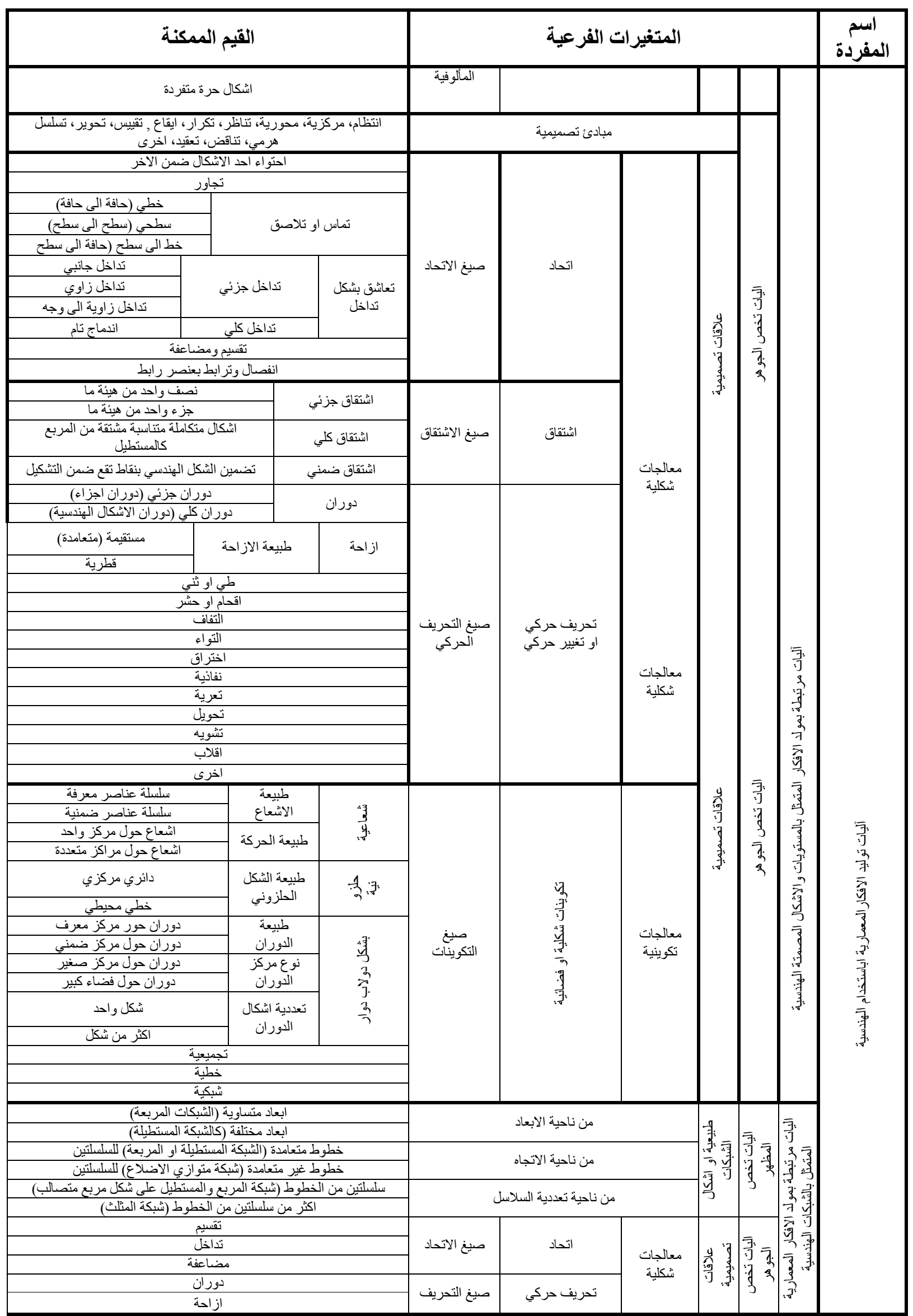




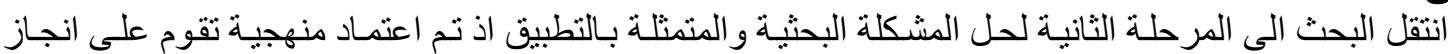

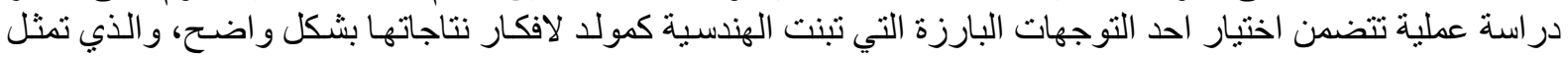

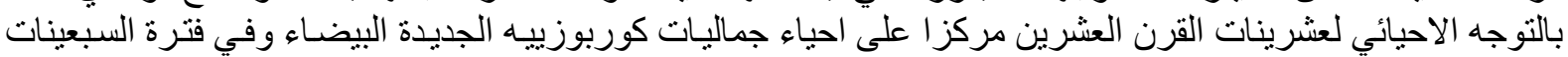

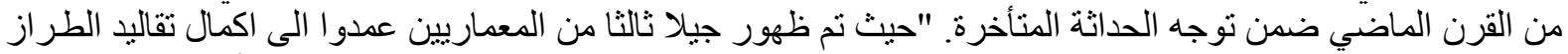

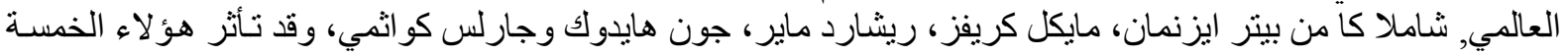

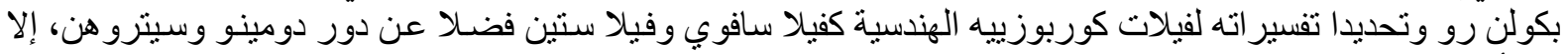

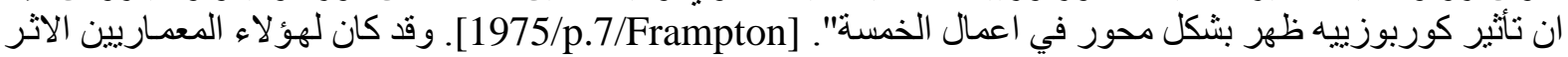

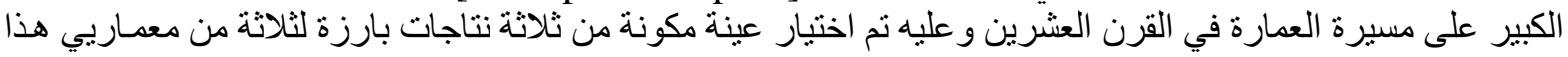

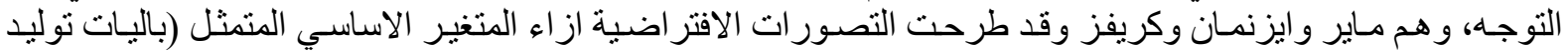

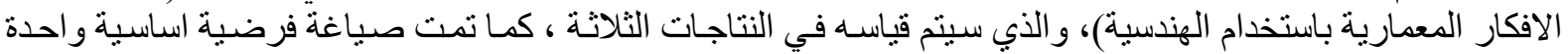

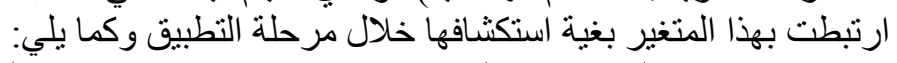

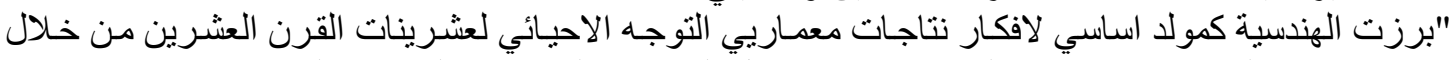

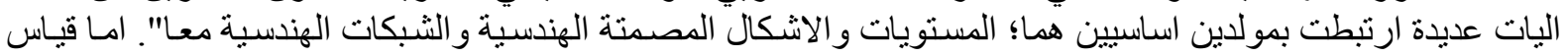

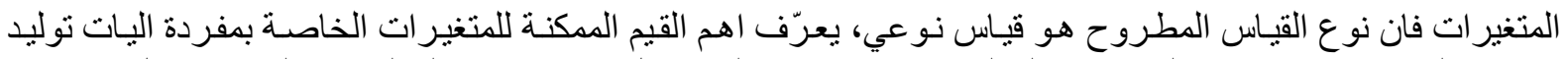

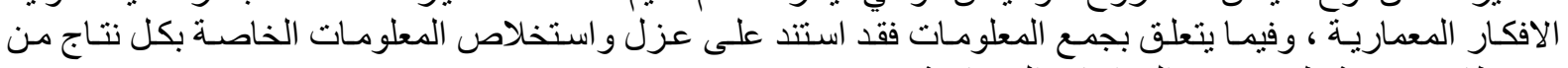

ملاحظات وصفية طرحت في الدر اسات المعمارية.

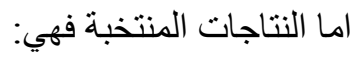

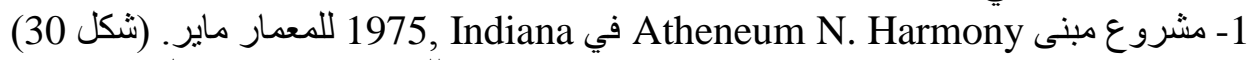

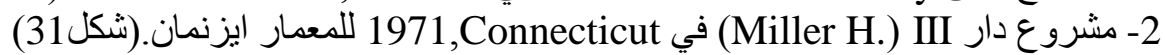

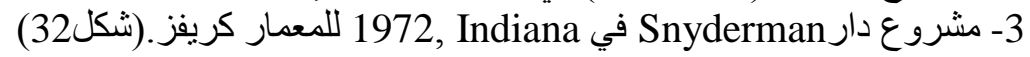

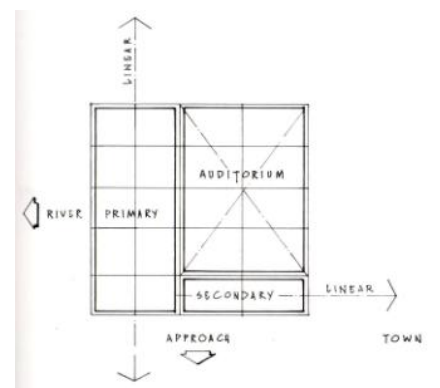

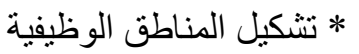

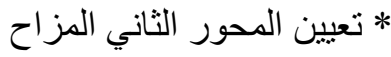
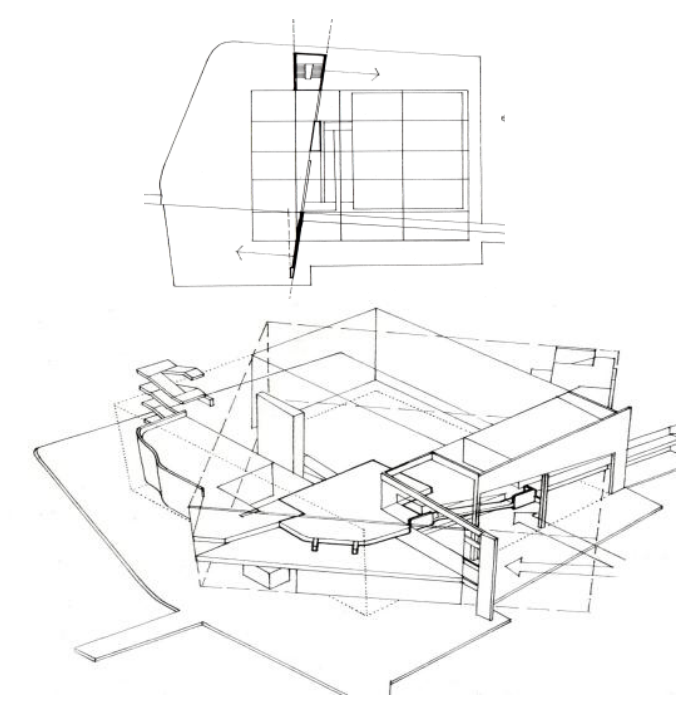
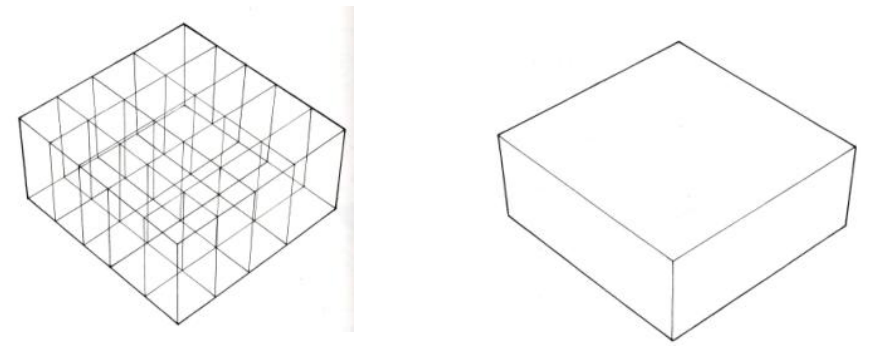

* تحوير الصندوق المكعب الثنكل * تقسيم الثبكة الهندية المتعامدة * تعيين المرتقى المائل في مركز المربع * تعيين المحور المزاح
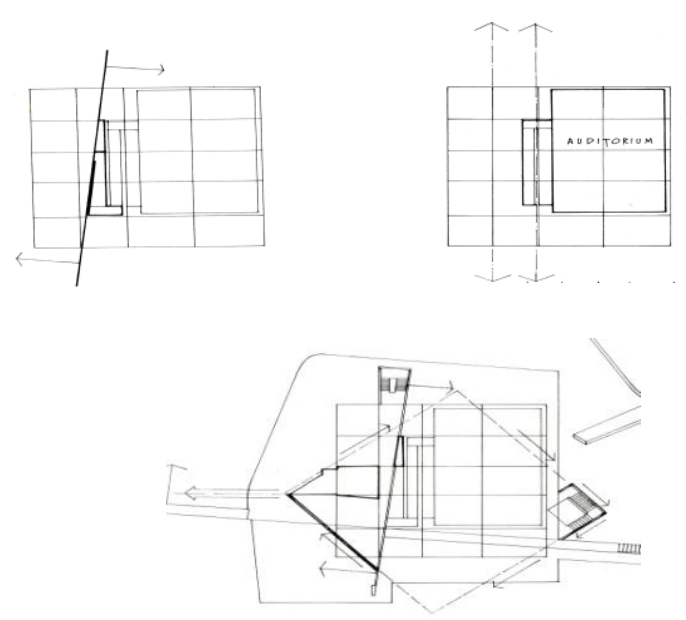

* دور ان مربع اكبر على المربع الاصلية ئنسي التعرية و التموج للكتلة. 


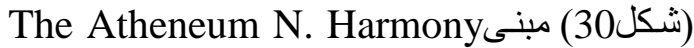
1975,

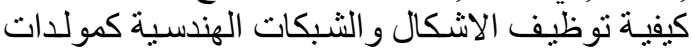

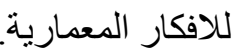
مصدر الاشكال:[1996/p.187-216/Baker]

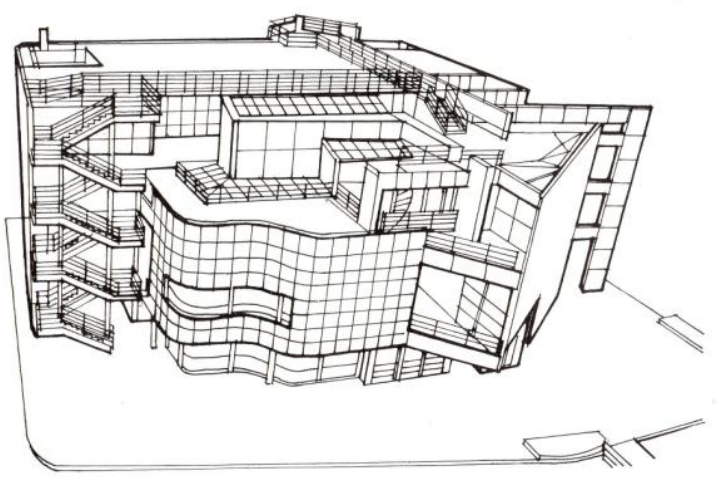

جدول (1-5): استمارة قياس المتفيرات لمشروع مبنى The Antheneum في Indiana للمعمار ريشـارد مساير عام المصدر: الباحث

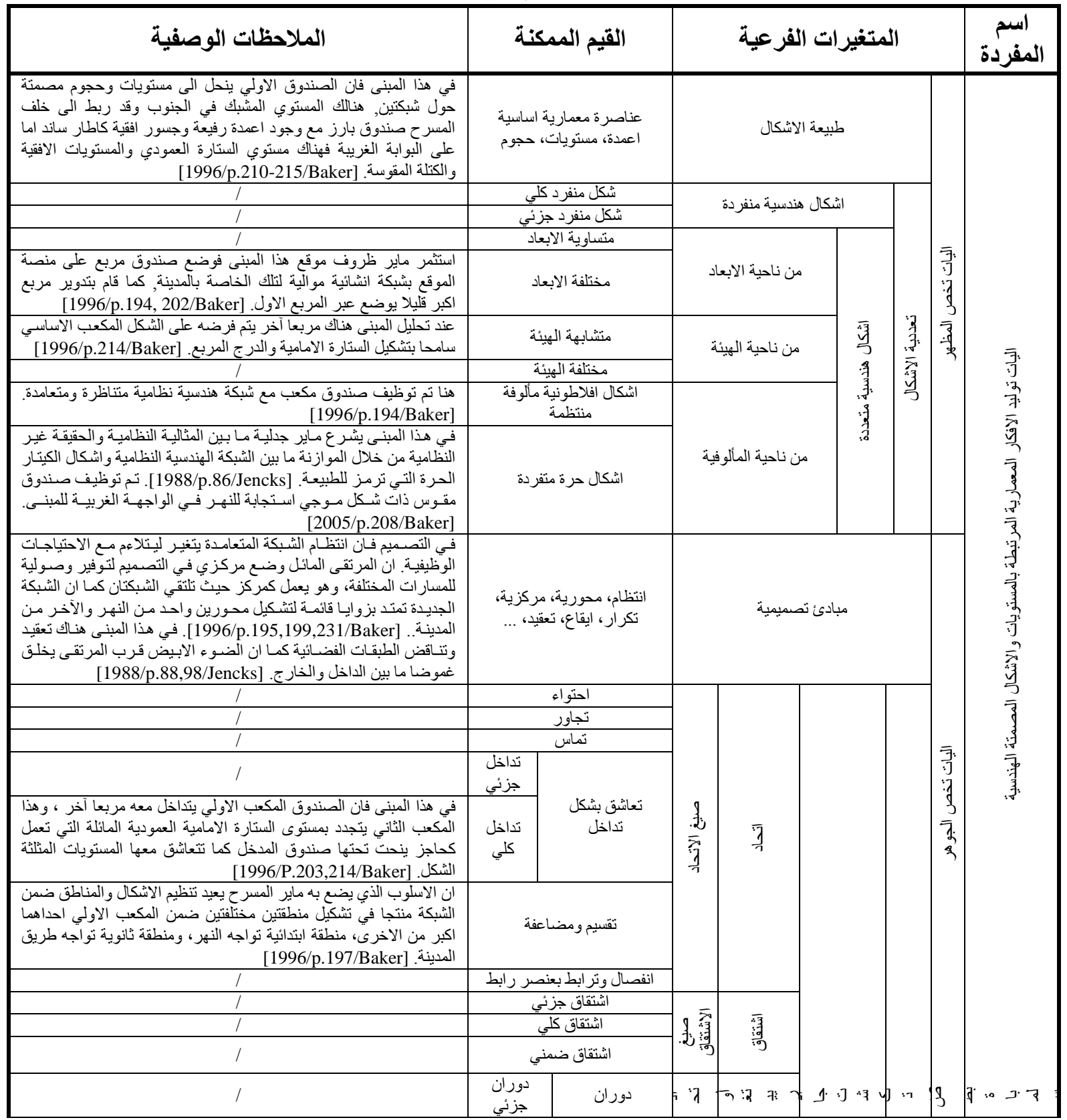




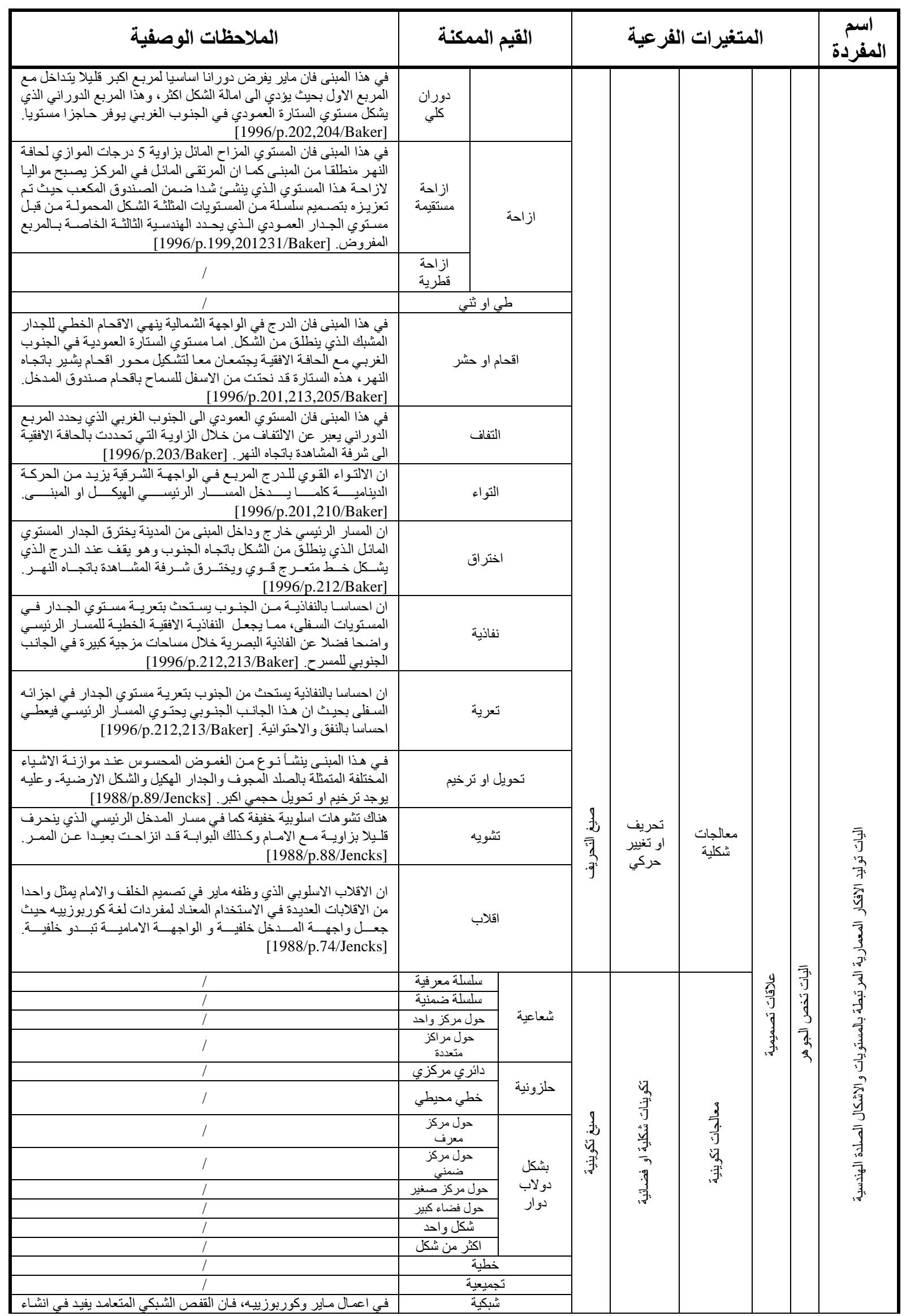




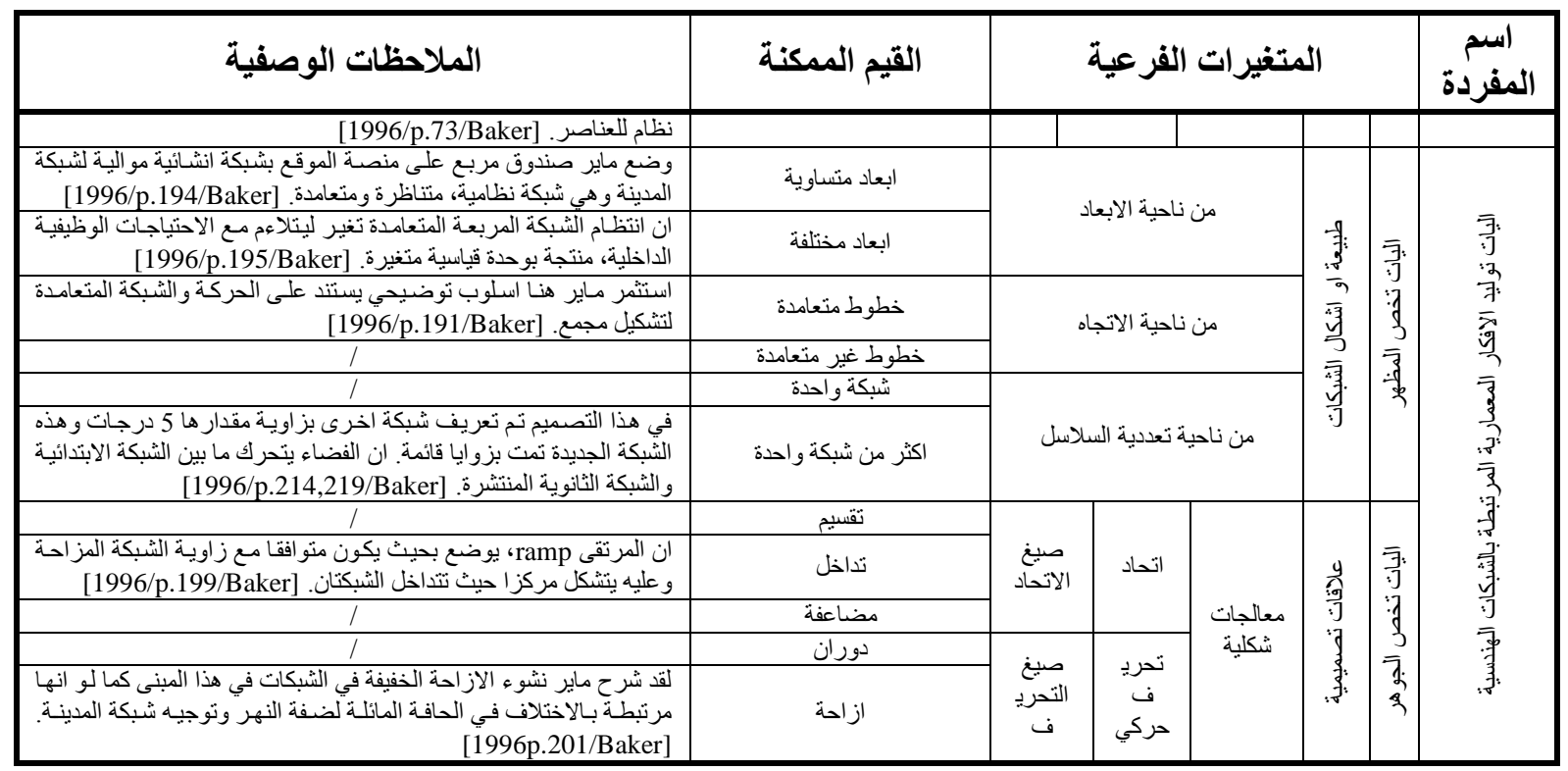
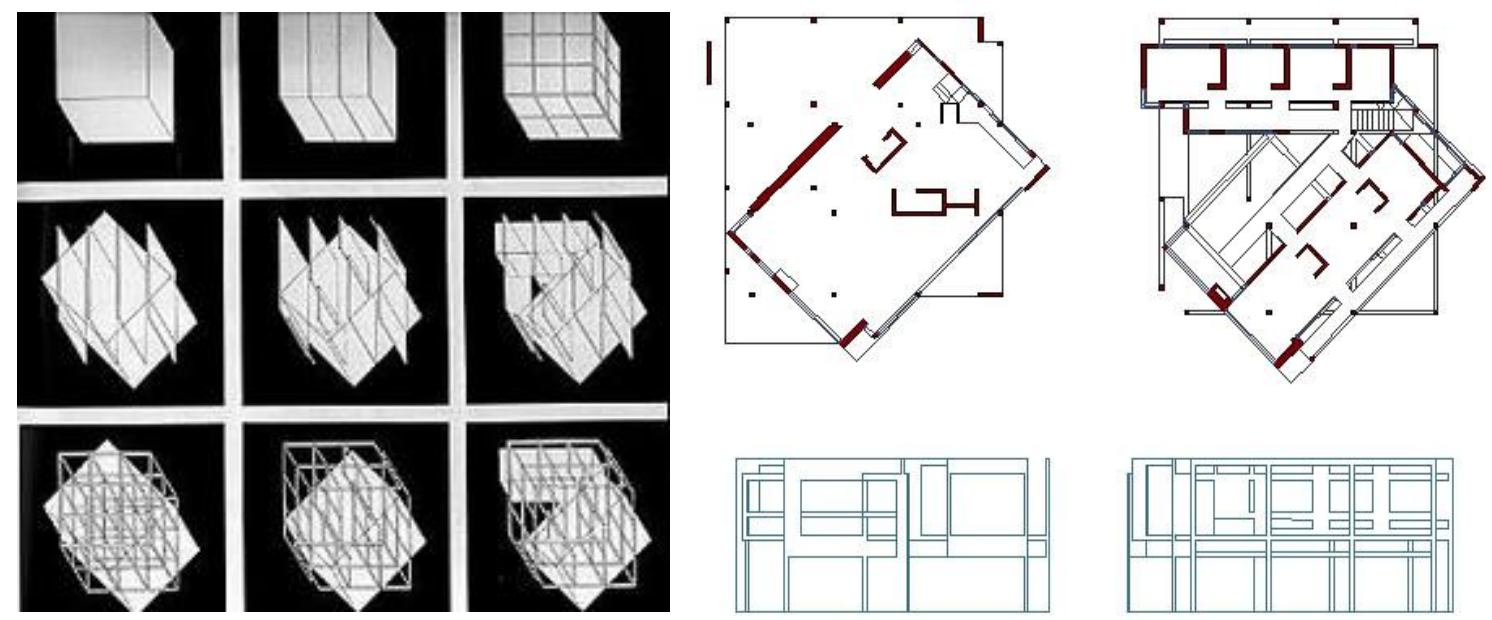

III المخططات الافقية و الو اجهات و المجسم لدار

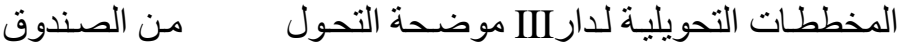
المكعب إلى الثبكة العموديـة إلى المستويات إلى ازاحسة المربـع ثم المثر

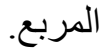

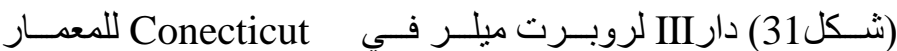

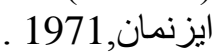
[1996/p.77/Ching],[1988/p.85/Jencks):المصدرن

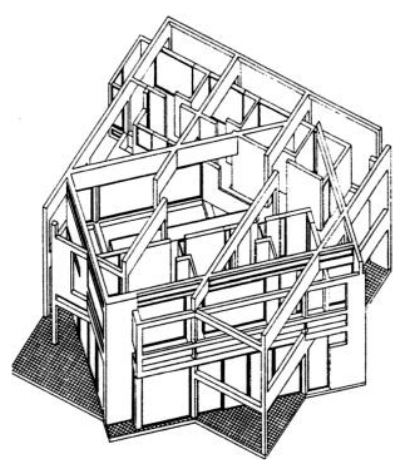

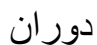


جدول (2-5): استمارة قياس المتغيرات لمشروع دار III لروبرت ميلرفي Connecticut عام 1971 للمعمسار بيتر المصدر: الباحث ايزنمان.

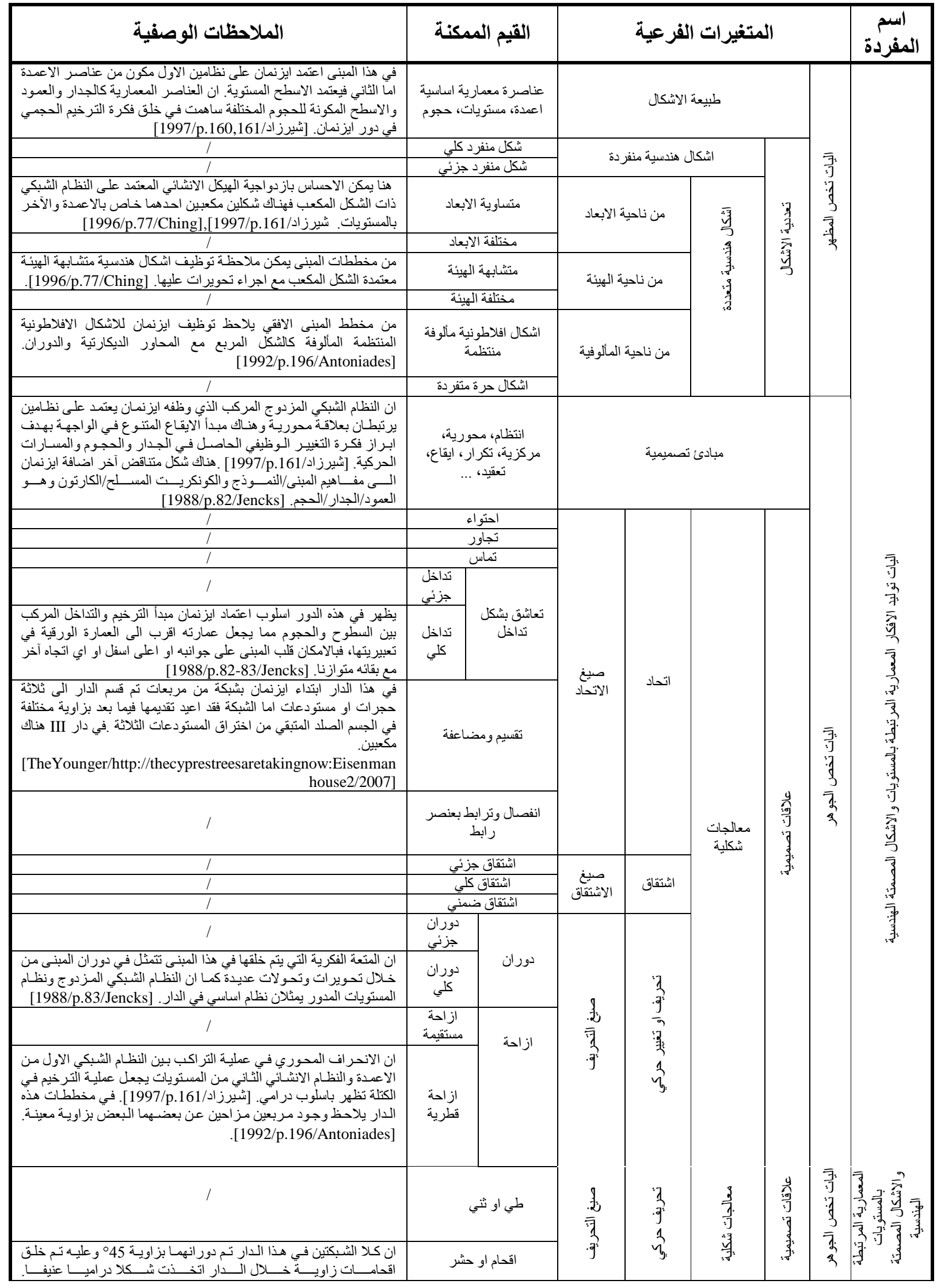




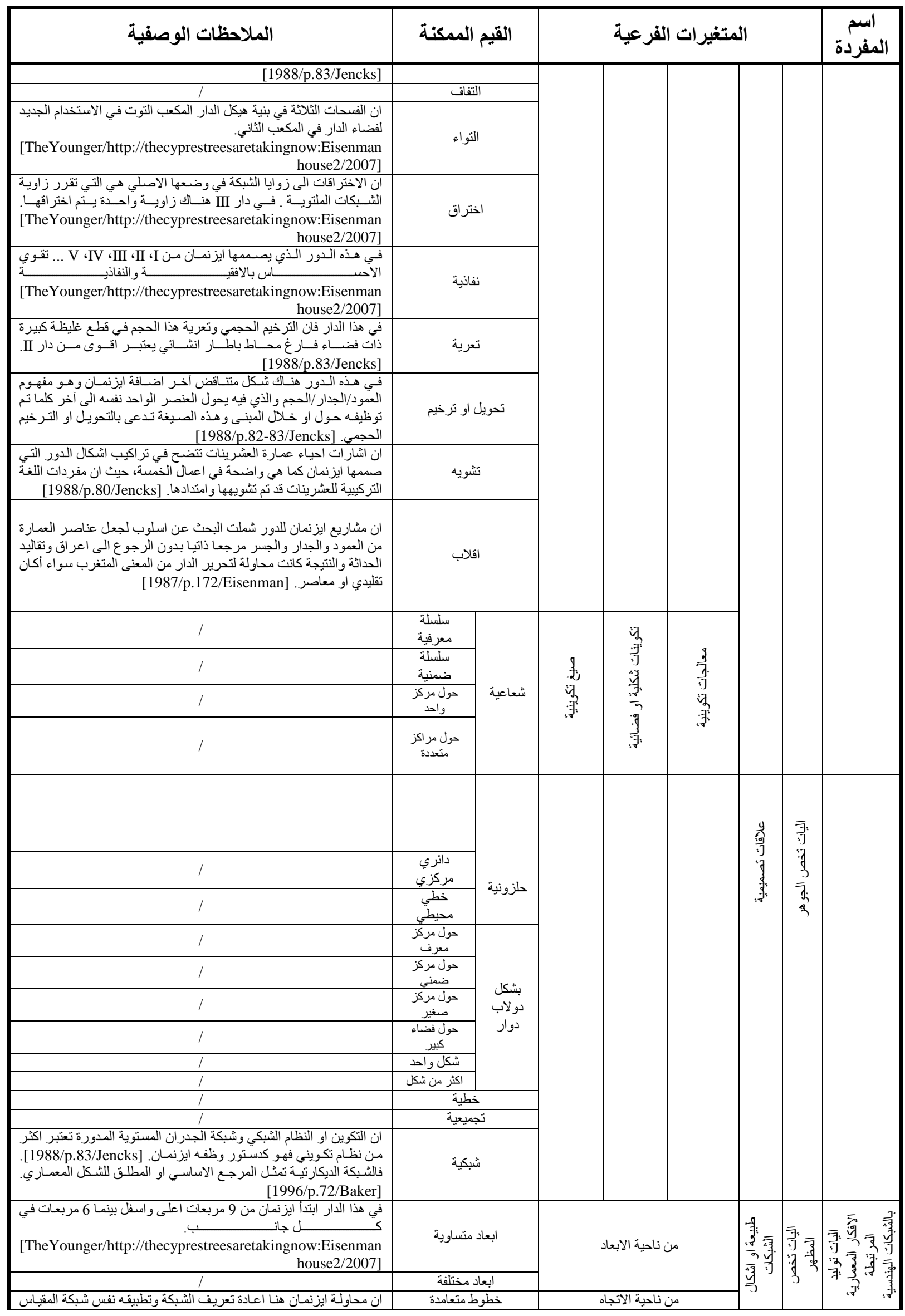


ألثيخ: توظيف الهندسية في توليد الافكار المعمارية في التوجه الاحيائي لعشرينات القرن العشرين

\begin{tabular}{|c|c|c|c|c|c|c|c|}
\hline الملاحظات الوصفية & القيم الممكنة & \multicolumn{5}{|c|}{ المتغيرات الفرعية } & المفردة \\
\hline اللايكارتية على كل الوجوه الستة تعتبر جديدة، كما ان دار III يتكون من & & \multirow{5}{*}{\multicolumn{3}{|c|}{ من ناحية تعددية السلاسل }} & \multirow{10}{*}{ 参 } & \multirow{10}{*}{ 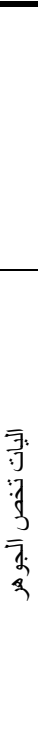 } & \\
\hline $\begin{array}{r}\text { [TheYounger/http://thecyprestreesaretakingnow:Eisenman } \\
\text { house } 2 / 2007]\end{array}$ & & & & & & & \\
\hline & خطوط غير متعامدة & & & & & & \\
\hline 1 & شبكة واحدة & & & & & & \\
\hline 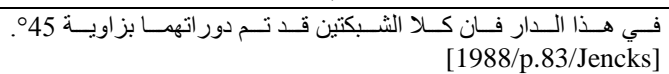 & اكثر من شبكة واحدة & & & & & & \\
\hline 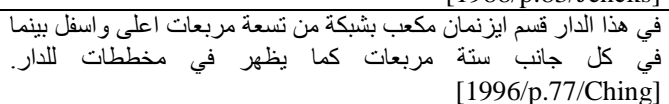 & تقسيم & \multirow{3}{*}{ الاتحماد } & \multirow{3}{*}{ اتحاد } & \multirow{3}{*}{ 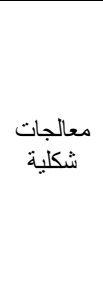 } & & & \\
\hline 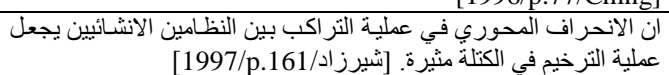 & تداخل & & & & & & \\
\hline 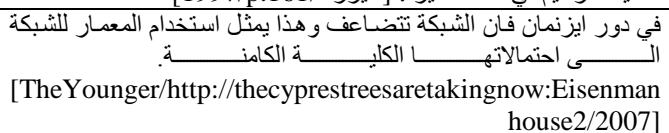 & مضاعفة & & & & & & \\
\hline 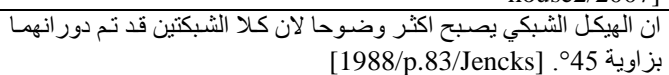 & دوران & \multirow[b]{2}{*}{ التحريغ } & \multirow[b]{2}{*}{ تحريف } & \multirow[b]{2}{*}{ ت معبيقية } & & & \\
\hline 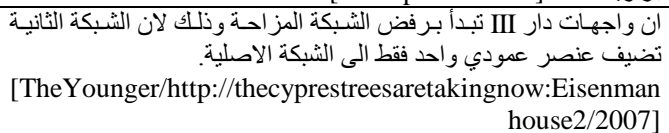 & ازاحة & & & & & & \\
\hline
\end{tabular}
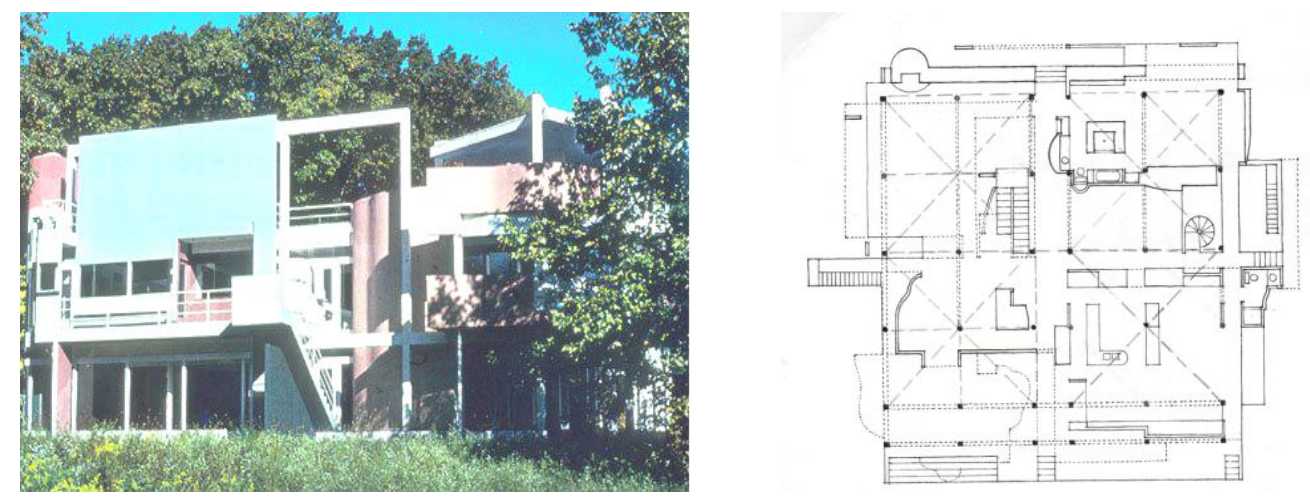

(شكل32) المخطط الافقي و الو اجهة لدار Snyderman لكريفز, , 1972

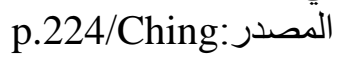

جدول (5-1-5): استمارة قياس المتفيرات لدار Snyderman House في Indiana للمعمار مايكل كريفز عام 1972.

المصدر: الباحث

\begin{tabular}{|c|c|c|c|c|c|c|}
\hline الملاحظات الوصفية & القيم الممكنة & \multicolumn{4}{|c|}{ المتغيرات الفرعية } & 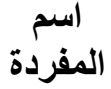 \\
\hline 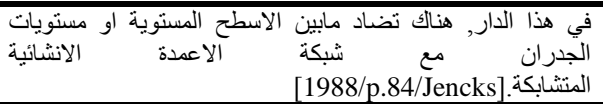 & اعداصرة، معتوارية، اسوسية & \multicolumn{3}{|c|}{ طبيعة الاشكال } & \multirow{6}{*}{ 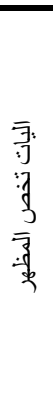 } & \multirow{6}{*}{ 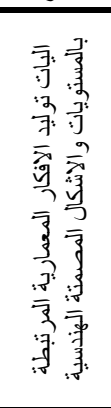 } \\
\hline 1 & شكل منفر در جز كلي & \multicolumn{2}{|c|}{ اشكال هندسية منفردة } & \multirow{5}{*}{ 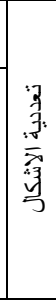 } & & \\
\hline 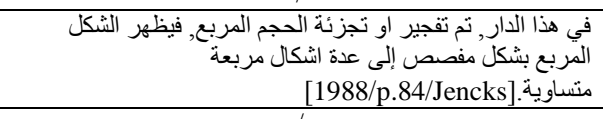 & منساوية الابعاد & \multirow[t]{2}{*}{ من ناحية الابعاد } & \multirow{4}{*}{ 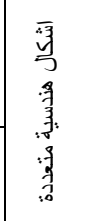 } & & & \\
\hline & مختلفة الابعاد & & & & & \\
\hline 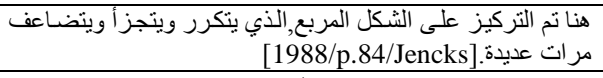 & متثابهة الهيئة & \multirow{2}{*}{ من ناحية الهيئة } & & & & \\
\hline 1 & مختلفة الهيئة & & & & & \\
\hline
\end{tabular}




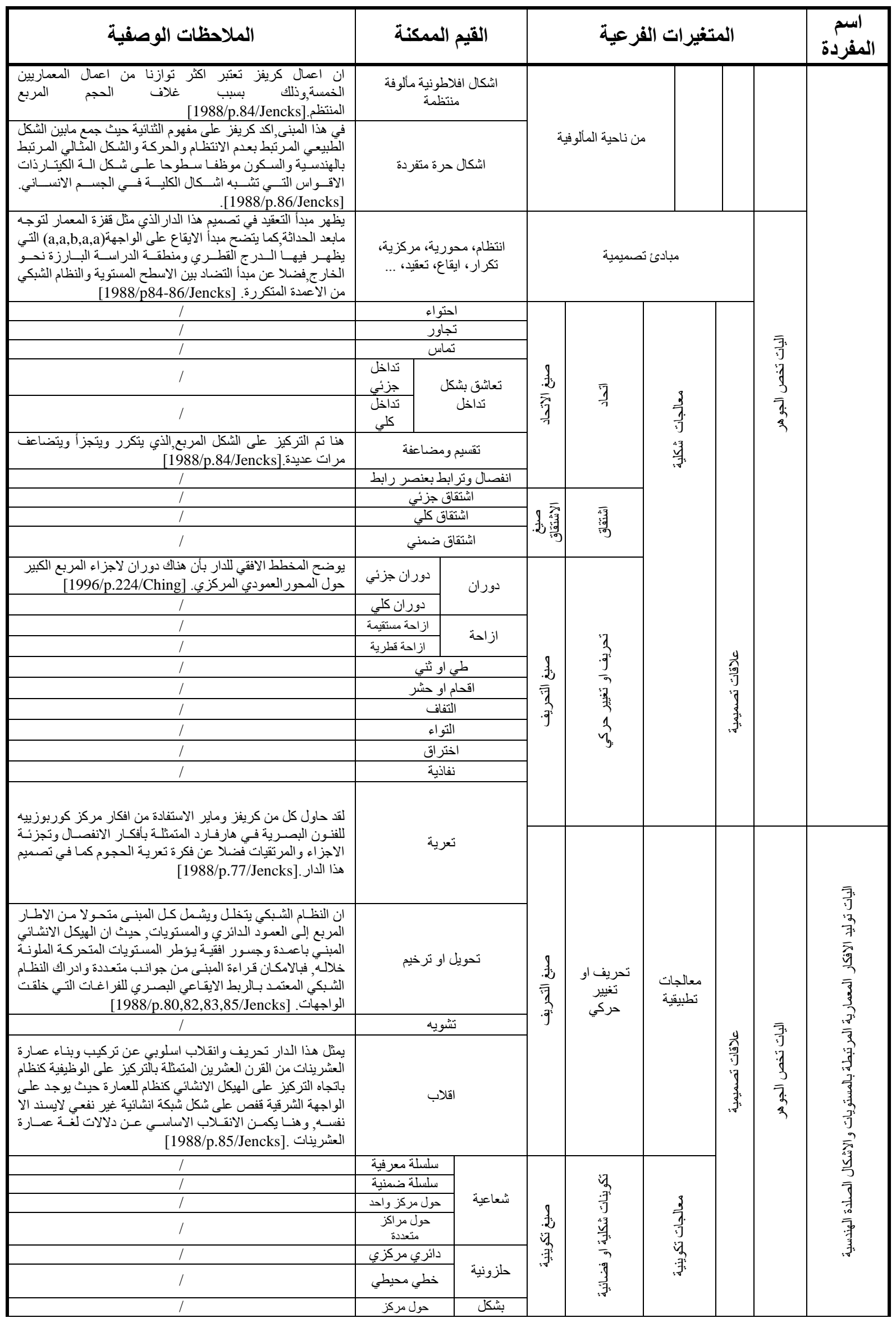




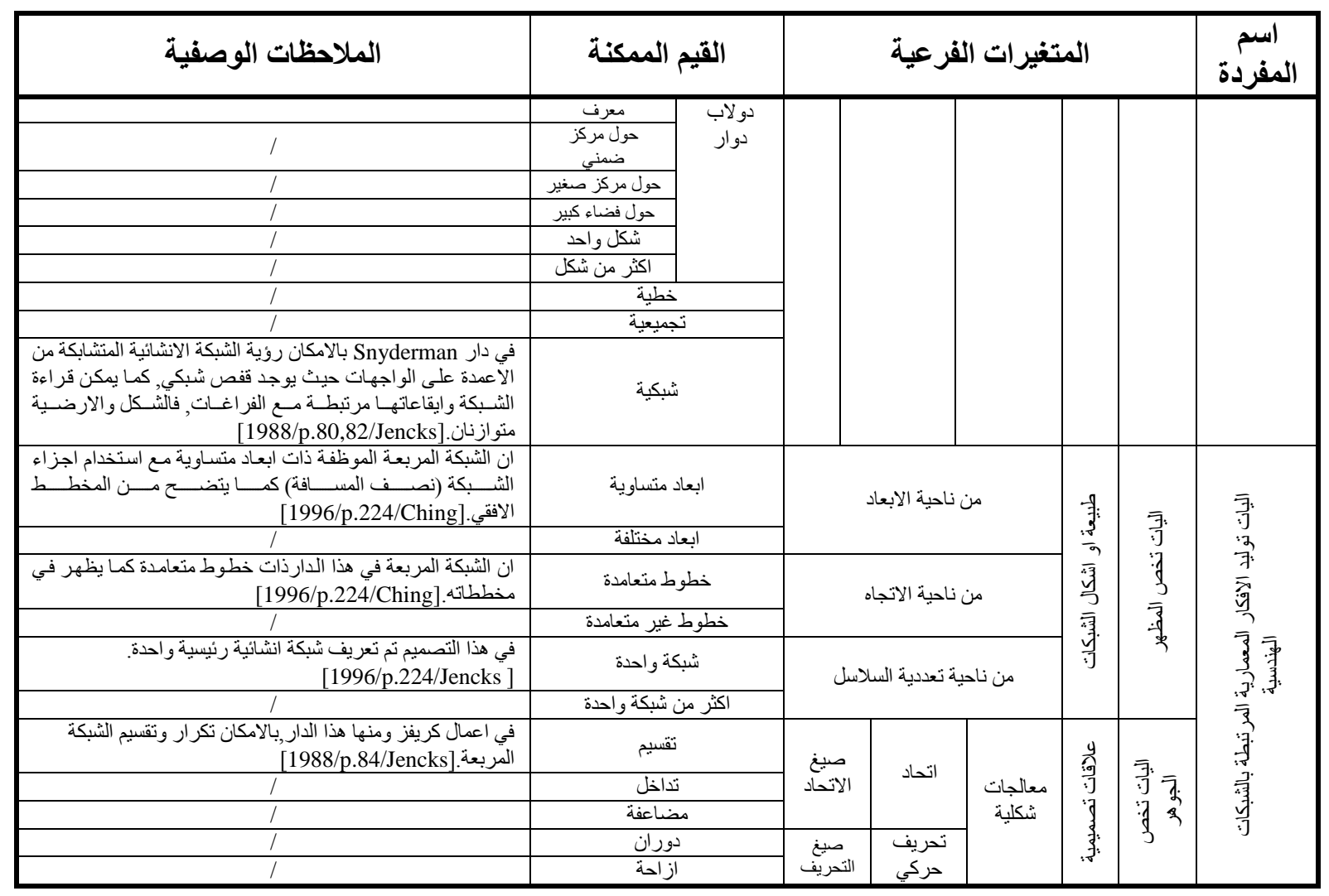

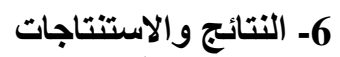

1-6 - مناقشة النتائج الخاصة بمفردة اليات توليد الافكار المعمارية باستخدام الهندسية

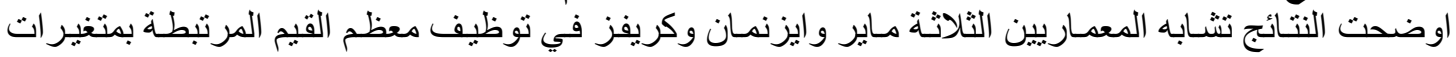

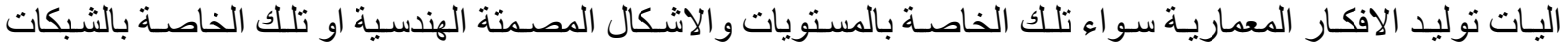

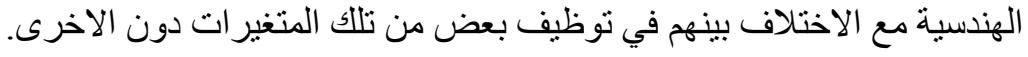

\section{1-1-6 - نتائج متغير اليات توليا الافكار المعمارية المرتبطة بالمستويات والاشكال المصمتة الهندية} أ. اليات تخص المظهر

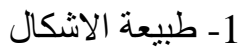

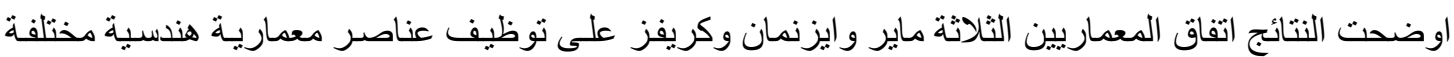

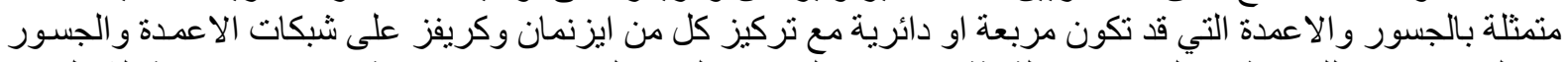

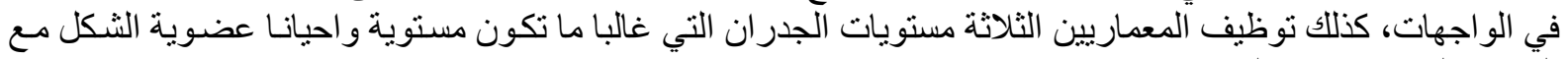

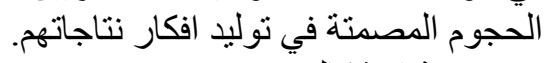
2- 2 - تعدية الاشكال

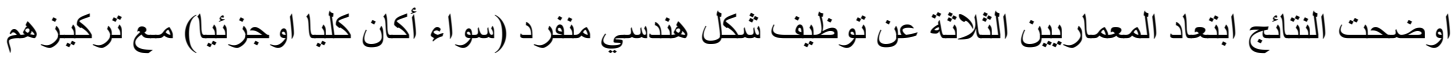

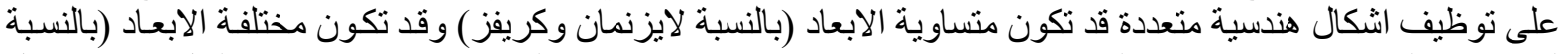

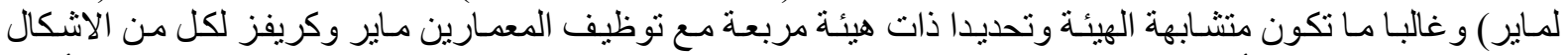

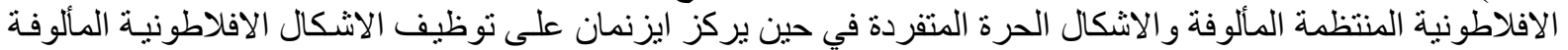

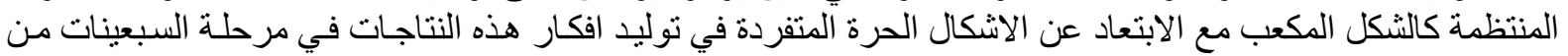

$$
\begin{aligned}
& \text { القرن الماضي. } \\
& \text { ب. اليات تخص الجو هر } \\
& \text { 1- مبادئ تصميمية }
\end{aligned}
$$




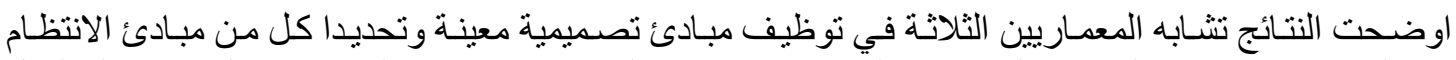

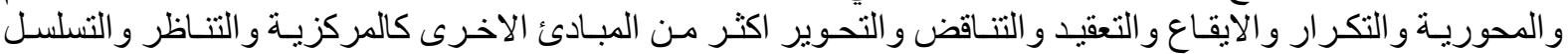

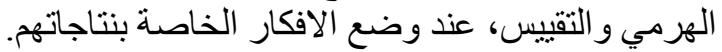
2- 2 علاقات تصميمية

تبين من النتائج تركيز المعماريين الثنلاثتة على العلاقات التصميمية وتحديدا المعالجات الثكلية بشكل تحريف حركي مع بعض المعالجات التكوينية عند توليد الفين الفكار نتاجاتهم وكما يلي:

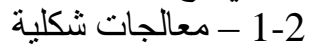

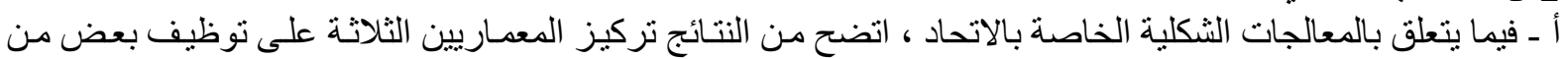

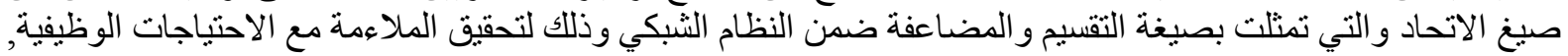

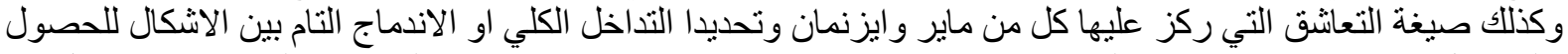

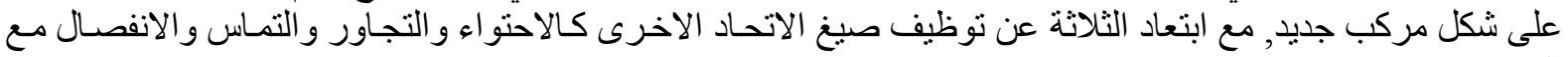
التر ابط بعنصر ر رابط. بـفيما يتعلق بالمعالجات الثكلية بشكل تحريف حركي، فقد حرص كل كل من ماير وايزنمـان وكريفز على توظيف معظم

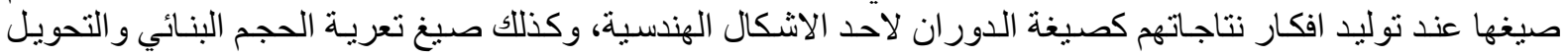

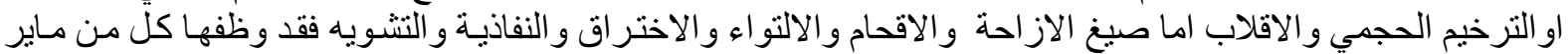

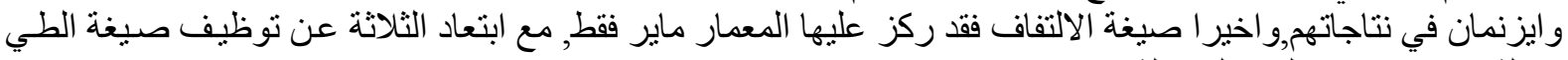
او الثني في نتاجاتهم لهذه المرحلة. 2-2 - 2- معالجات تكوينية

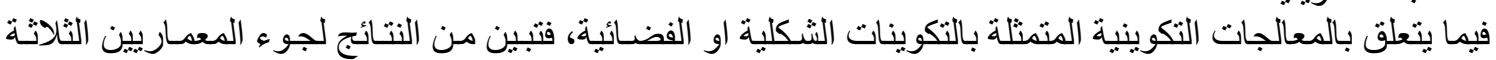

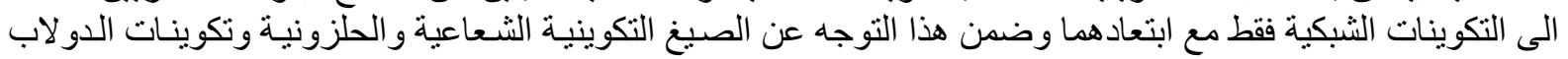
الدو ار و الخطية و التجميعية النيكة

2-1-6 - نتائج متغير اليات توليد الافكار المعمارية المرتبطة بالثبكات الهندسية أ. اليات تخص المظهر

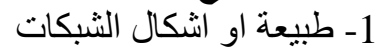

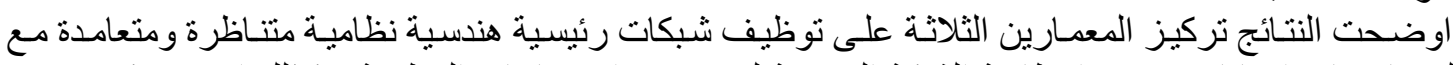

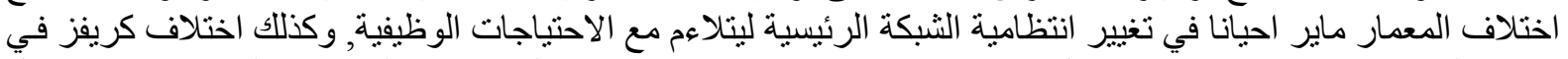

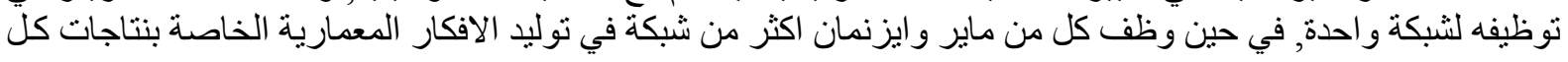

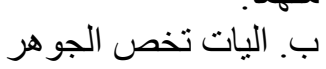
2- 2 - 2 علاقات تصميمية

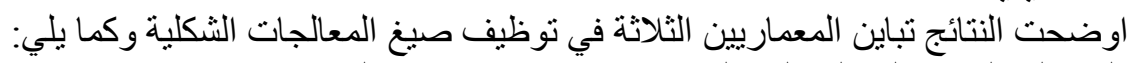

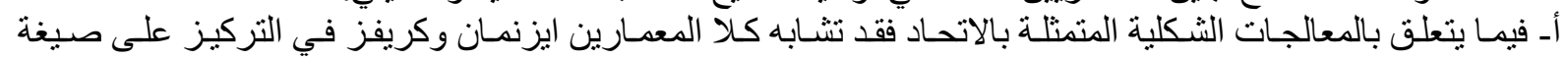

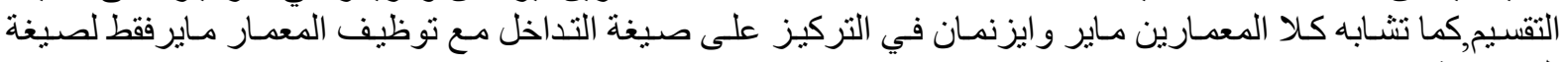
المضاعفة.

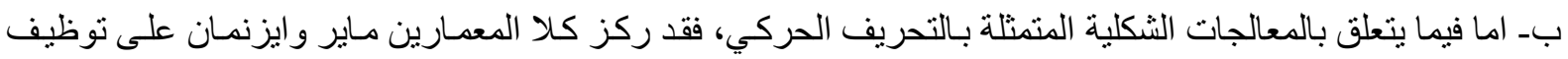

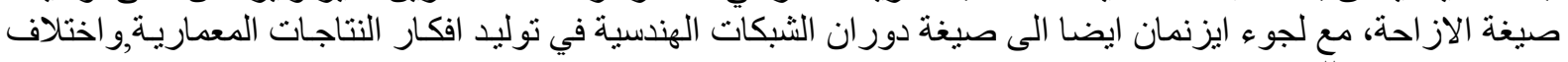
كريفز عنهما في ذللك.

2-6 - الاستنتاجات النهائية الخاصة بتوظيف الهندسية في توليد افكار النتاجات المعمارية

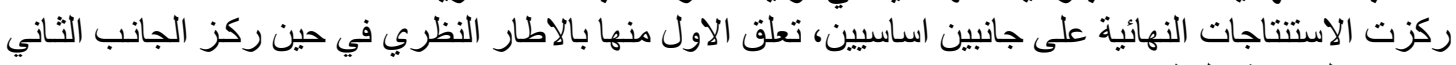

$$
\text { على الاستنتاجات الخاصة بالاتطبيق. }
$$

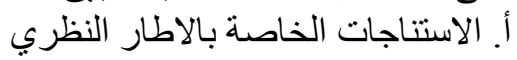

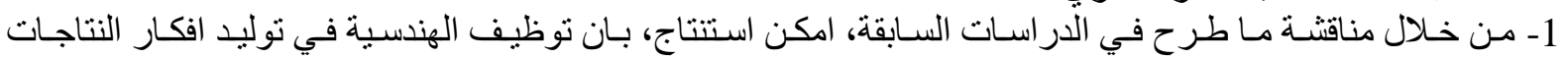

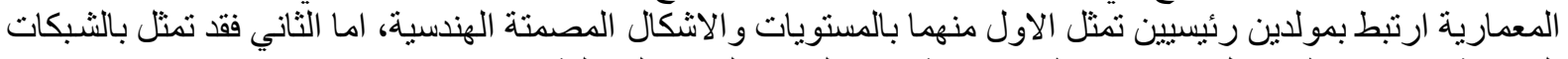

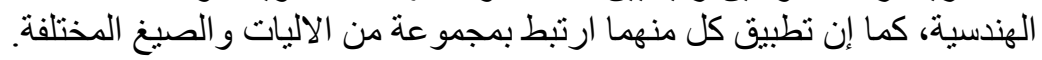

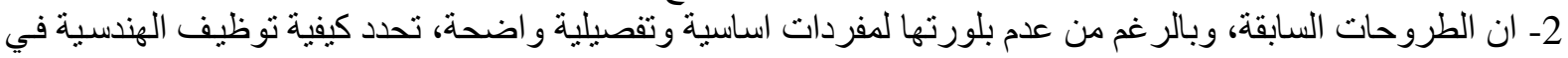

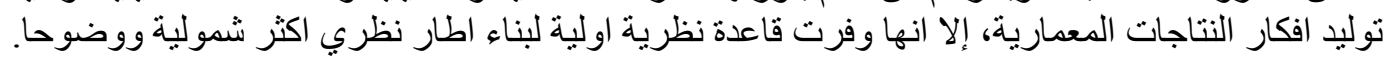




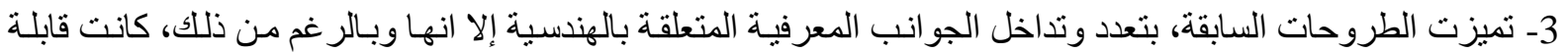
اللترتيب في مجمو عة متر ابطة محكمة، تم توظيفها لاستخلاص المفردة الاساسية لموضو ع البحث و المنمثلة باليات نوليد الافكار المعمارية باستخدام الهندسية.

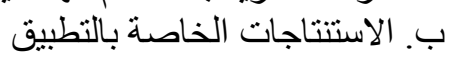

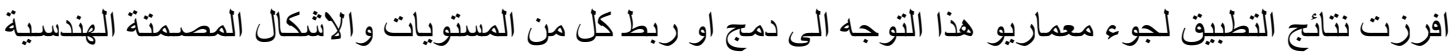

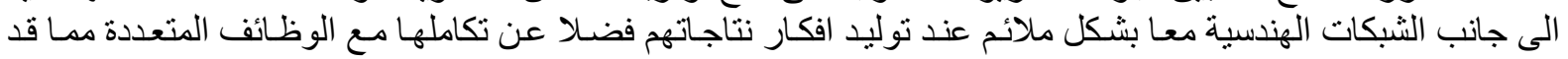

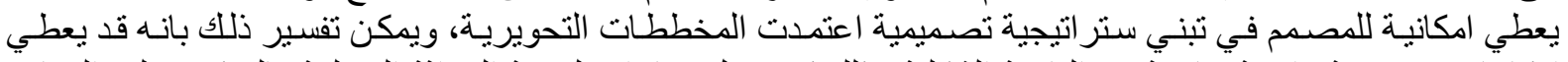

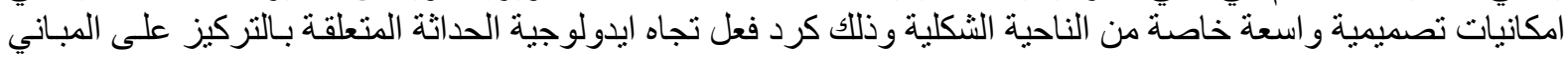

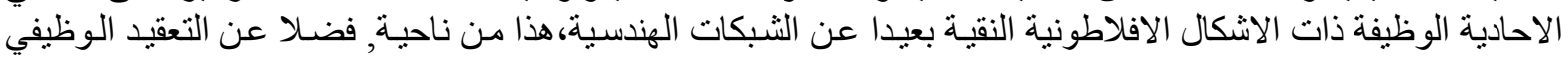

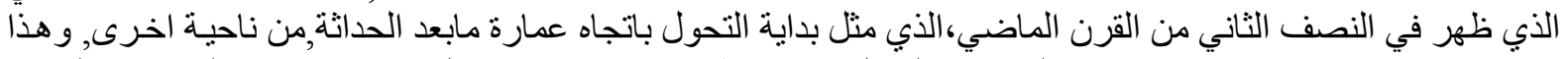

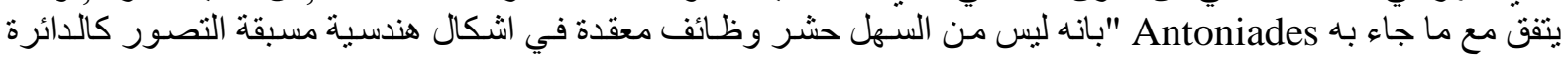

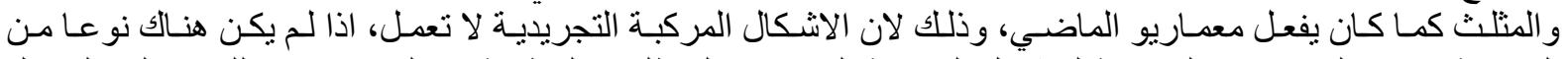

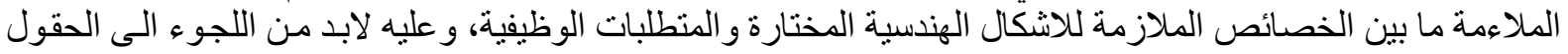

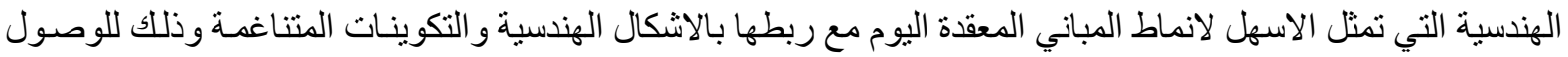

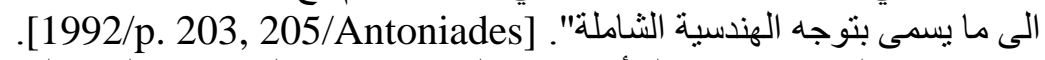

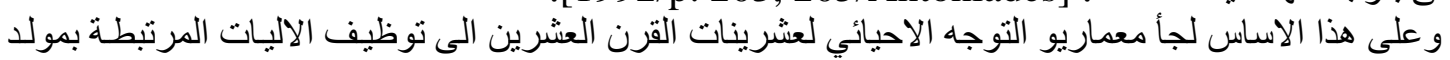

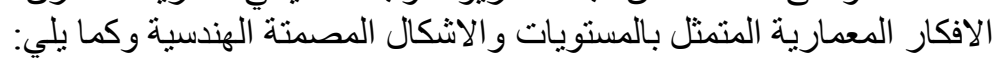

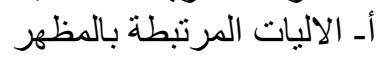

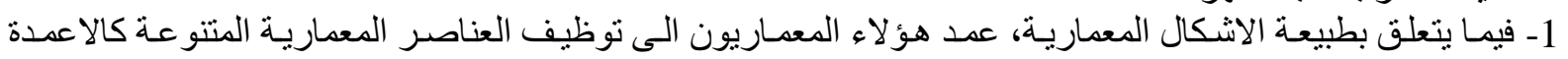

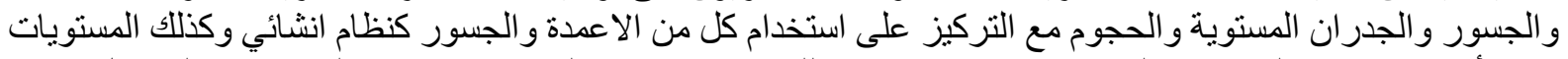

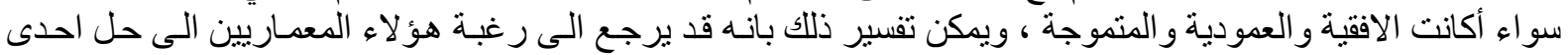

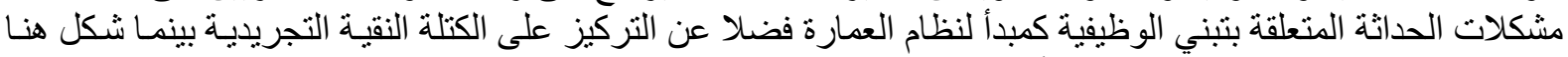

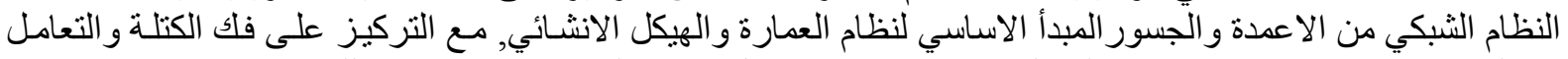

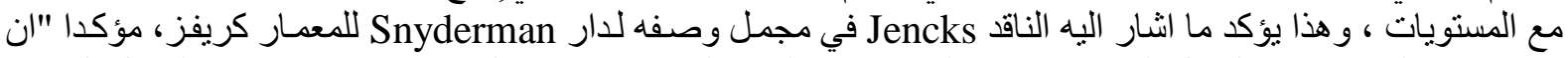

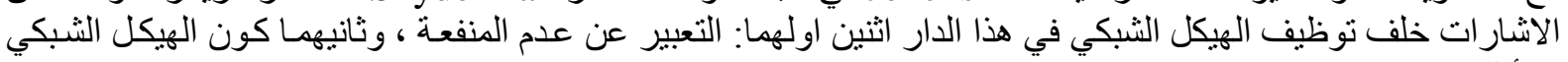

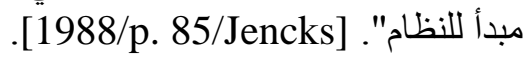

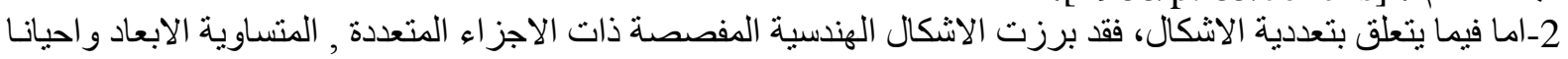

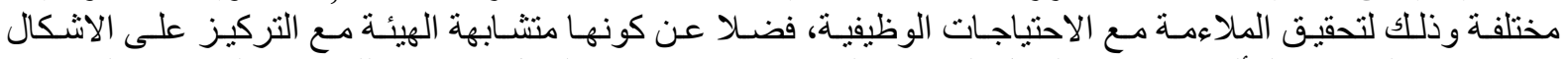

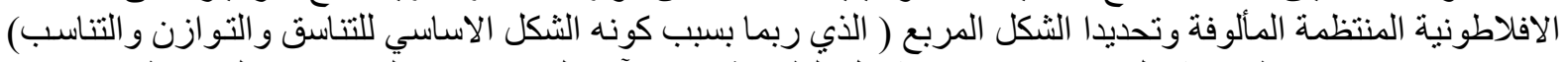

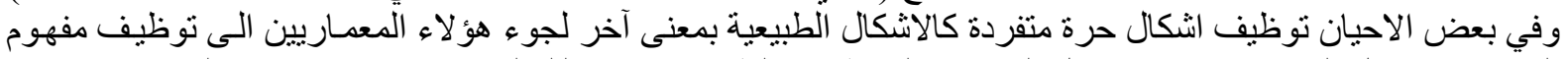

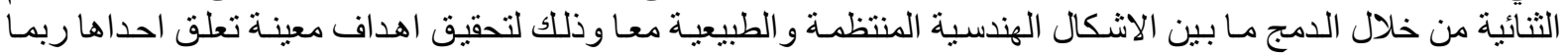

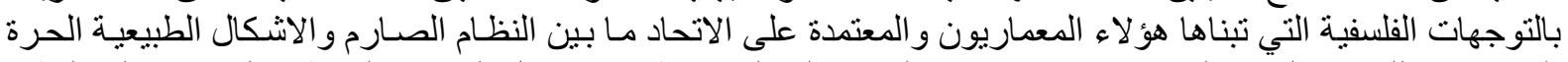

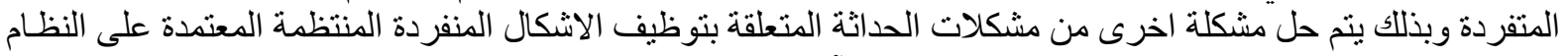

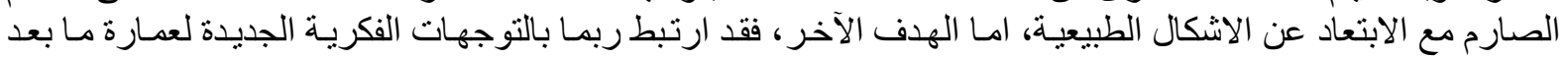

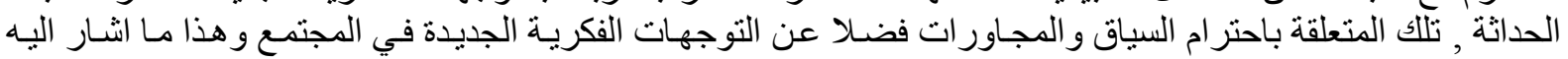

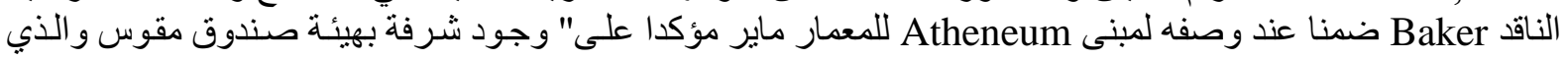

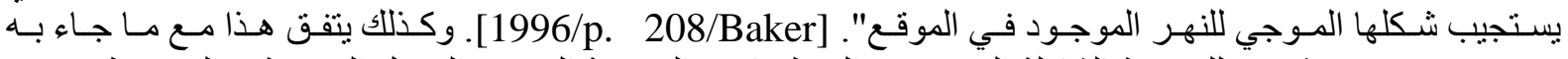

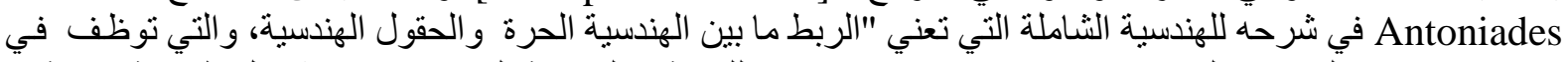

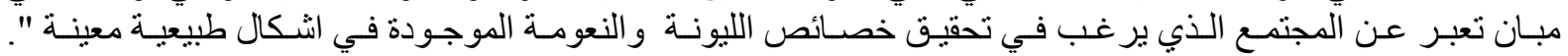

.[1992/p. 198/ Antoniades]

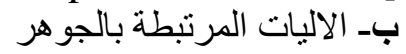

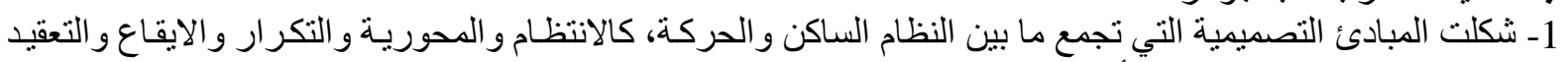

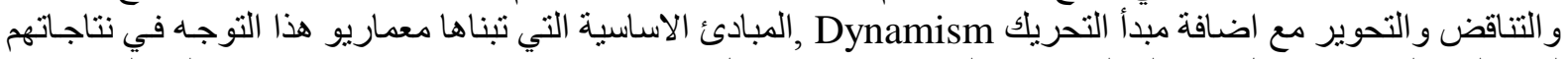

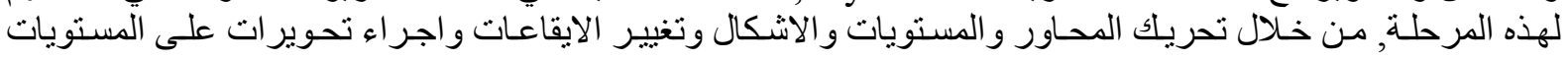

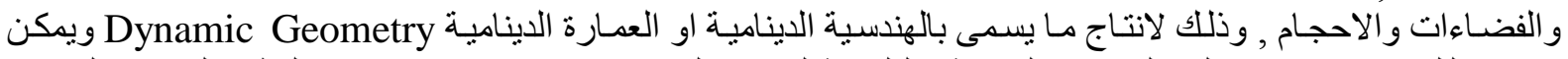

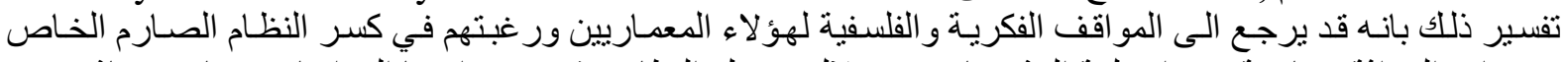

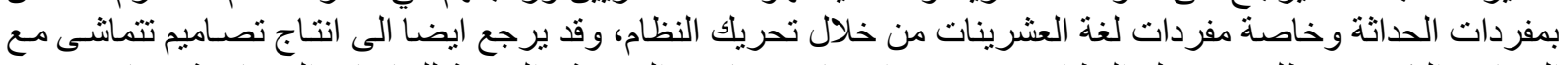

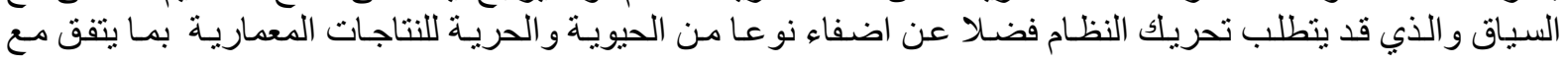


منطلبات العصر، و هذا التفسير ربما يتفق مـع مـا اشـار اليه الناقد Antoniades عند "شرحه لمفاهيم الهندسية وتحديدا هندسية اليوم مؤكدا, ارتباطها بحالة من القلق و عدم الثبات و الحركة في العمارة بهدف استكثاف آفاق جديدة و الوصول التهال التى

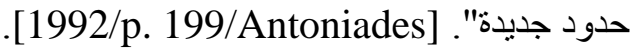
2- برزت العلاقات التصميمية ذات المعالجات الثنكلية بشكل تحريف حركي بجميع صيغها (من دوران الاشكال واز احتها

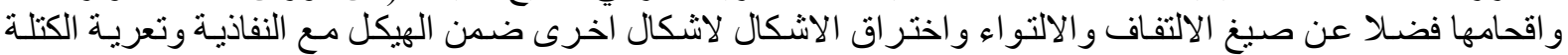

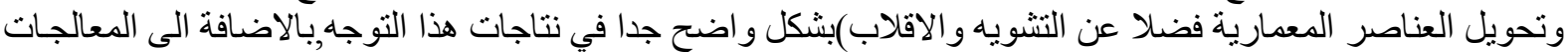

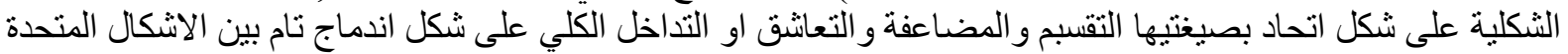

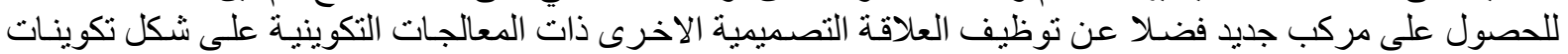

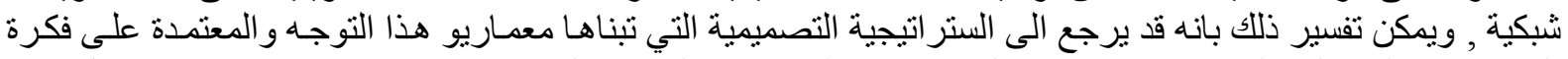

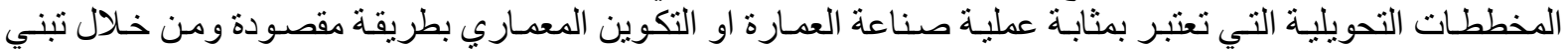

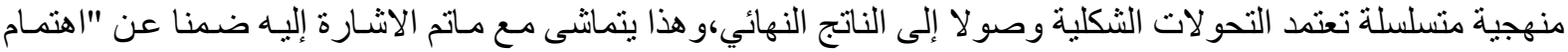

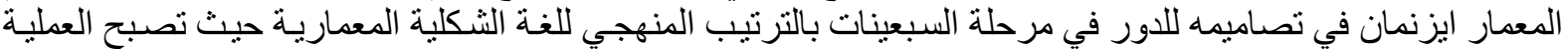
التصميمية سلسلة من التحوير ات , يستبدل العنصر نفسه بآخر كانقسام الحجم الى مستويات و المستويات المتو ازيـة تصبح شبكة و الثبكة تدور و هكذا". .http://caad,arcg,ethz.ch/teachinh/nds/ws98/script/object/stobject3.html/2008]/Eisenman] كما لجأ معدـاريو هذا التوجها ايضـا، الـى توظيف الاليات المرتبطة بمولد الافكار المعماريـة المتمثل بالثبكات

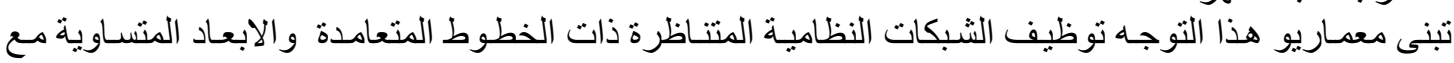

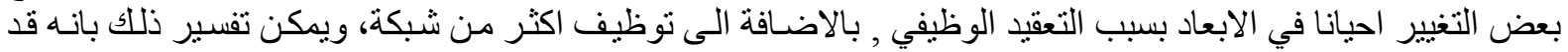

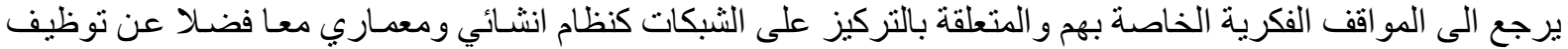

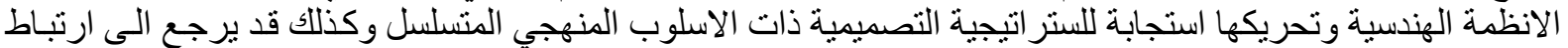

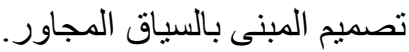

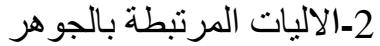

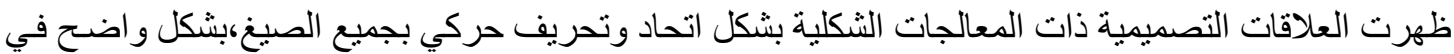

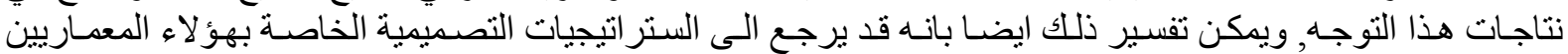

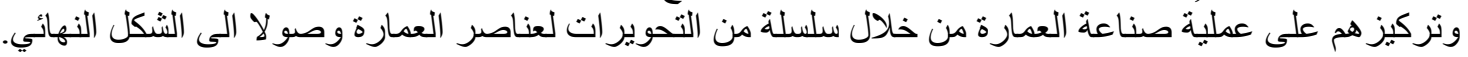

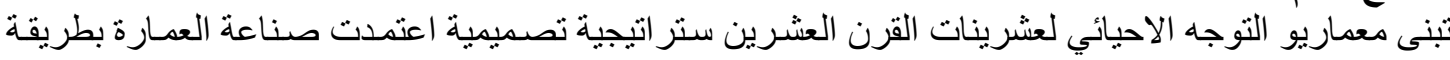

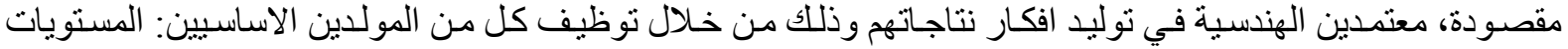

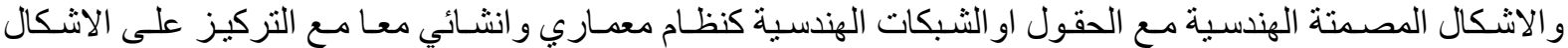

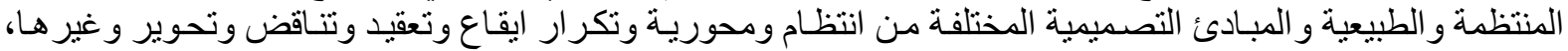

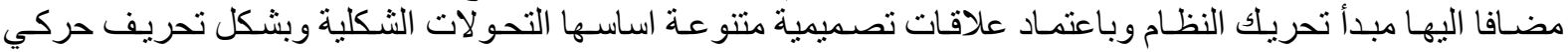

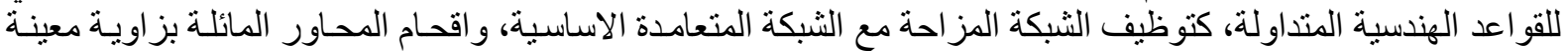

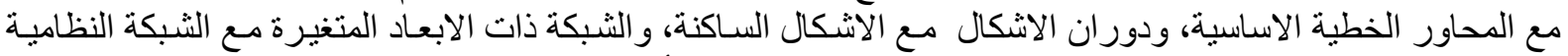

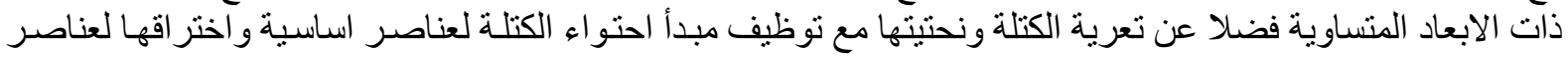

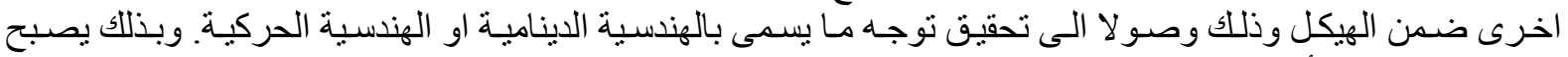

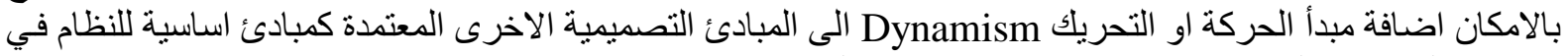
الادبيات المعمارية المتخصصة بشر الفرح عناصر ومبادئ العمارة.

1- يوصي البحث باستتمار ما تم التوصل اليه فيما يتعلق بالمقياس المطروح و الخـاص بمفردة الاطار النظري ضدمن هذا

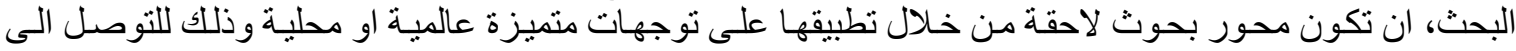

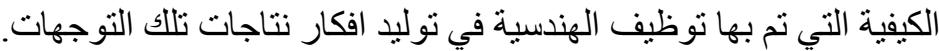

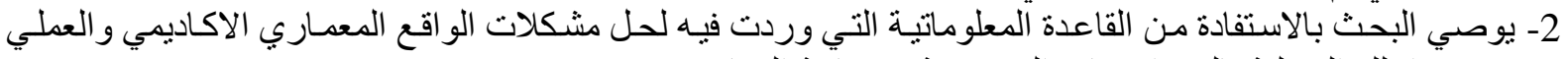
وتحديدا تلك المتعلقة بالستر اتيجيات التصميمية وصناعة العاعة العمارة. 
1- شيرز اد، شبرين، 1997، "الاسلوب العالمي في العمارة بين المحافظة و التجديد"، دار الثؤون الثقافية العامة، بغداد. 2-Antoniades, "Poetics in Architecture", "Theory of design" John Wiley and Sons, Inc., U.S.A., 1992

3-Baker, Geoffery, "Design Strategies in Architecture, an approach to the analysis of form, $2^{\text {nd }}$ Edition, Van Nostrand Reinhold, E. and FN Spon, U.S.A., 1996.

4-Ching, Francis, “Architecture, Form, Space, and Order", $2^{\text {nd }}$ Edition, John Wiley and Sons, Inc., 1996, U.S.A.

5-Clark, Pause, Roger, Michael, "Precedents in Architecture, Analytic, Diagrams, Formative Ideas, and Partis, $3^{\text {rd }}$ Edition, John Wiley and Sons, Inc., 2005, U.S.A.

6-Eisenman, Peter, "Commentary on the Alteka Office Building Japan", Architectural Design Profile, no.102.

http://caad.arch.ethz.ch/teaching/nds/ws98/script/object/folding.html.

7-Eisenman, Peter, "Misreading in Houses of Cards", Oxford University Press, 1987. http://caad.arch.ethz.ch/teaching/nds/ws98/script/object/st-object3.html, 2008.

8-Eisenman, Peter,

http://caad.arch.ethz.ch/teaching/nds/ws98/script/object/st-object3.html, 2000.

9-Eisenman, Peter,

http://www.answers.com/topic/petereisenman/2008.

10-Frampton, Kenneth, "Introduction to Richard Meier Architect, Buildings and Projects 1966-97, New York: Oxford University Press, 1976.

11-Jencks, Charles, “Architecture Today”, London, Academy Editions, 1988.

12-The Younger Anonymous, http://thecypresstreesaretalkingnew, Eisenman House 2, 2007.

$$
\text { تم اجراء البحث في كلية ألهندسة = جامعة ألموصل }
$$

